\title{
Thin Film Composite and/or Thin Film Nanocomposite Hollow Fiber Membrane for Water Treatment, Pervaporation, and Gas/Vapor Separation
}

\author{
Kailash Chandra Khulbe *(D) and Takeshi Matsuura \\ Industrial Membrane Research Laboratory (IMRL), Chemical and Biological Engineering Department, \\ University of Ottawa, Ottawa, ON K1N 6N5, Canada; matsuura@eng.uottawa.ca \\ * Correspondence: kc_khulbe@yahoo.com
}

Received: 8 June 2018; Accepted: 4 September 2018; Published: 20 September 2018

\begin{abstract}
Thin film composite (TFC) polymeric hollow fiber (HF) membranes are widely used in industrial gas/vapor separations and water treatment. There are many advantages of TFC HF membranes, such as low energy requirements, simplicity of operation, and high specificity. In the present article, a review is made on the progress that has been achieved during the past 15 years in the preparation of the HF substrate and the preparation/modification of the thin selective layer. The review also includes their applications in water treatment, dehydration of alcohols via pervaporation, and gas/vapor separation.
\end{abstract}

Keywords: thin composite hollow fiber; water treatment; water vapor separation; dehydration of alcohols; pervaporation

\section{Introduction}

Hollow fiber membranes (HFMs) are artificial membranes, with a semi-permeable barrier in the form of hollow fiber, were developed in the 1960s for reverse osmosis (RO) applications. Since then, they have been successfully applied in water treatment, desalination, cell culture, and in medical and pharmaceutical fields [1]. Hollow fiber membranes are highly efficient and very popular due to their low energy requirements, simplicity of operation, and high specificity qualities. The performance of an optimized hollow fiber nanofiltration (NF) module is $100 \%$ better than an optimized spiral-wound module [2]. A very large membrane area of HF can be packed into a single module, which is the most significant advantage.

A highly porous substrate coated with a dense film of a different polymer is usually called a thin film composite (TFC) membrane. For RO, a thin film composite (TFC) membrane is a multi-layer membrane in which an ultrathin semipermeable membrane layer is deposited on a finely microporous support structure [3]. Among several methods devised for the preparation of composite membranes, interfacial polymerization is used most often. Cadotte [4] fabricated for the first time the selective polyamide film by interfacial polymerization of m-phenylene diamine (MPD) and trimesoyl chloride (TMC), which is still used widely.

\section{Method of Making Thin Film Composite (TFC) Hollow Fiber (HF)}

\subsection{Fabricating Hollow Fiber}

There are four techniques to fabricate HFMs.

i Melt spinning: In this process, a melted thermoplastic polymer is extruded through a spinneret into air and is subsequently cooled. 
ii Dry spinning: Polymer solution in an appropriate solvent is extruded through a spinneret into air.

iii Dry-jet wet spinning: Polymer solution in an appropriate solvent is extruded through a spinneret into air and a subsequent coagulant (usually water).

iv Wet spinning: Polymer solution in an appropriate solvent is extruded directly into a coagulant (usually water).

A spinneret is used in all the above techniques. The use of a spinneret is common. A spinning dope, prepared by dissolving polymer in a proper solvent or by melting, is forced through a metal nozzle that has fine holes to form a filament. As soon as the dope solution emerges from the nozzle in the form of long fibers, it solidifies by evaporation of solvent, cooling, or coagulation. A schematic diagram for the formation of a hollow fiber is shown in Figure 1. The properties, such as average pore diameter and wall thickness of the HF, depend on the spinning parameters which are as follows:

i Dimensions of the spinneret;

ii driving force;

iii temperature;

iv length of air gap (for dry-jet wet spinning);

$\mathrm{v}$ coagulant;

vi composition of "dope" (polymer) and "bore" (coagulant) solutions; and

vii speed at which produced fiber is collected by a motorized spool.

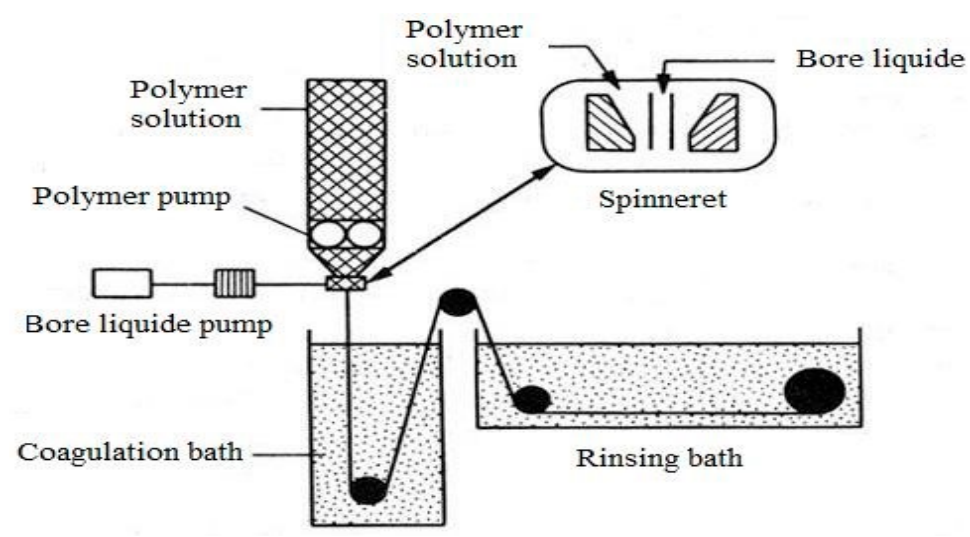

Figure 1. Apparatus for the fabrication of hollow fibers (HFs) [5].

During solidification following stages are involved:

i The diffusion of internal precipitant molecules into the concentrated hollow fiber forming polymer solution. At the same time, polymer coagulates (precipitates from solution) to form a solid phase;

ii in this stage, a cross-diffusion of solvent molecules from the polymer solution into the internal nonsolvent starts and it speeds up the coagulation of the polymer and the formation of the porous structure of the fiber body; and

iii during the evaporation of solvent molecules from the outer surface of the fiber into the air, the concentration of polymer on the outer surface of the fiber is increased, which is the cause of the formation of the dense (selective) polymer layer.

Chung's group [6] designed and fabricated a tri-bore blossom spinneret (Figure 2) for making a tri-bore thin-film composite (TFC) hollow fiber (HF) membrane. 
a

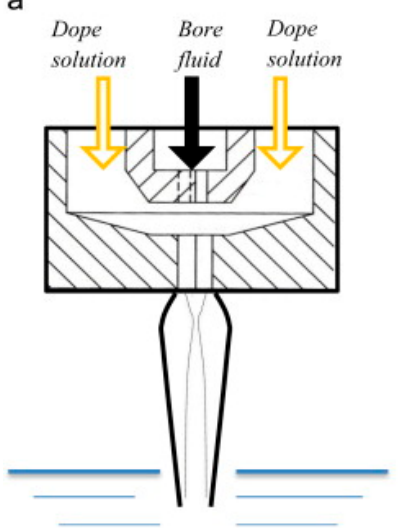

b

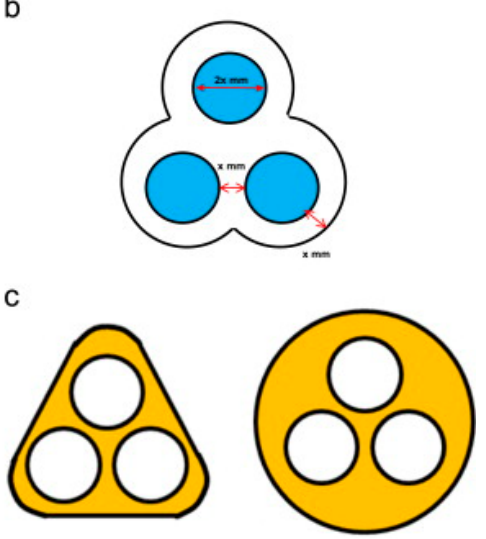

Figure 2. (a) Single layer tri-needle spinneret; (b) bottom view of the tri-needle spinneret; and (c) cross section [6].

\subsection{TFC Hollow Fiber Fabrication}

A composite membrane consists of a nano-thin selective dense layer and a porous substrate. By modifying the top selective layer and bottom porous substrate, the overall membrane performance can be maximised. There are many ways or techniques to make thin composite layers on the surface of a support. The most common ones are:

i Interfacial polymerisation reaction;

ii dipping method;

iii plasma treatment; and

iv chemical reaction.

There are also three other methods [7], but these are not very common:

i Chemical vapour deposition (CVD);

ii sputtering; and

iii spray pyrolysis.

The spray pyrolysis method has been successfully applied to produce fine metals or metal oxide particles. Li et al. [8] obtained a Pd-Ag alloy membrane on the surface of a porous alumina hollow fiber by spray pyrolysis of $\mathrm{Pd}\left(\mathrm{NO}_{3}\right)_{2}$ and $\mathrm{AgNO}_{3}$ solutions on a $\mathrm{H}_{2}-\mathrm{O}_{2}$ flame.

\subsubsection{Dip Coating}

In industries, coated fabrics are manufactured by dip coating. This technique is also common in academic research where thin film coating is needed. Thin film composite hollow fiber membranes are fabricated in the same way. There are five stages in the dip coating process [9]:

i Immersion: With a constant speed, the substrate is immersed in the solution of the coating material (preferably jitter-free);

ii start-up: The substrate has remained inside the solution for a while and is starting to be pulled up;

iii deposition: The thin layer deposits itself on the substrate while it is pulled up. To avoid jitters, the withdrawing should be at a constant speed. The thickness of the coating depends on the withdrawal speed (faster withdrawal gives a thicker coating material) [10,11];

iv drainage: Excess liquid will drain from the surface; and

$\mathrm{v}$ evaporation: A thin layer is formed on the surface by evaporation of the solvent. For volatile solvents, such as alcohols, evaporation starts during the deposition and drainage steps.

To fabricate thin films by self-assembly via the sol-gel technique, the dip coating method is generally used. Self-assembly can give a film thicknesses of exactly one monolayer. The sol-gel technique creates 
films of an increased, precisely controlled thickness that are mainly determined by the deposition speed and solution viscosity. Functional coatings are applied to change the surface properties of the substrate, such as adhesiveness and wettability.

\subsubsection{In-Situ Polymerization}

The most common technique to make a TFC hollow fiber membrane is by interfacial polymerization (IP) reaction. IP reaction to form polyamide dense layer is based on trimosyl trichloride (TMC) and 1,3-phenylenediamine (MPD). Figure 3 shows the IP between TMC and MPD. During IP, polymerization occurs at the interface between an aqueous solution containing one monomer and an organic solution containing a second monomer. The interfacial polymerization is a self growth polymerization. IP occurs in a mixed monolayer of the adsorbed monomers. When the interfacial pressure of the adsorbed mixed monolayer exceeds the equilibrium spreading pressure of the polymer, the latter is precipitated from the monolayer, giving rise to a thick film at the interface. There are numerous unstable oligomers (molecules) that must be synthesized in situ (i.e., in the reaction mixture, but cannot be isolated on their own) for use in various processes. Mostly, in TFC HF fabrication, the selective layer is deposited on the lumen side of the fiber.

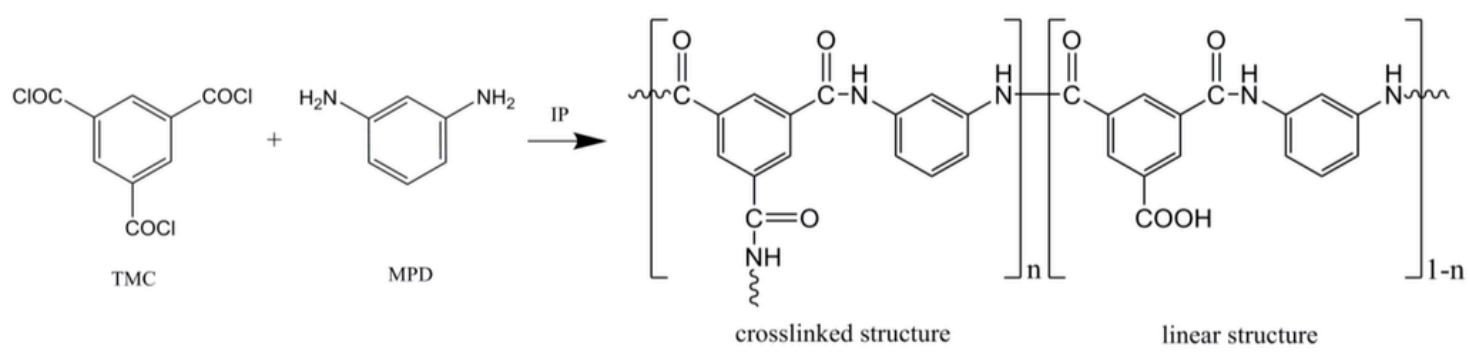

Figure 3. Interfacial polymerization (IP) between trimosyl trichloride (TMC) and 1,3phenylenediamine (MPD).

Urper et al. [12] discussed the recent developments in the design of TFC hollow fiber nanofiltration membranes and provided a comparative analysis of the two main methods of their fabrication:

i Interfacial polymerization; and

ii phase inversion.

To prepare integrally skinned hollow NF, the direct phase inversion (PI) method is commonly used in which the porous sublayer and the separation layer (membrane skin) are made of the same polymer. On the other hand, IP on phase-inverted membranes is used to prepare thin film composite (TFC) membranes where the porous support is made of a different material (typically polysulfone) than the skin layer (typically aromatic polyamide).

\section{Water Treatment}

Different types of membranes are used for softening, disinfection, organic removal, and desalination of water and wastewater. There are four types of membranes that are used for water treatment:

$\begin{array}{ll}\text { i } & \text { Ultrafiltration (UF); } \\ \text { ii } & \text { reverse osmosis (RO); } \\ \text { iii } & \text { nanofiltration (NF); and } \\ \text { iv } & \text { microfiltration (MF). }\end{array}$

Figure 4 shows the range of nominal membrane pore sizes [13]. 


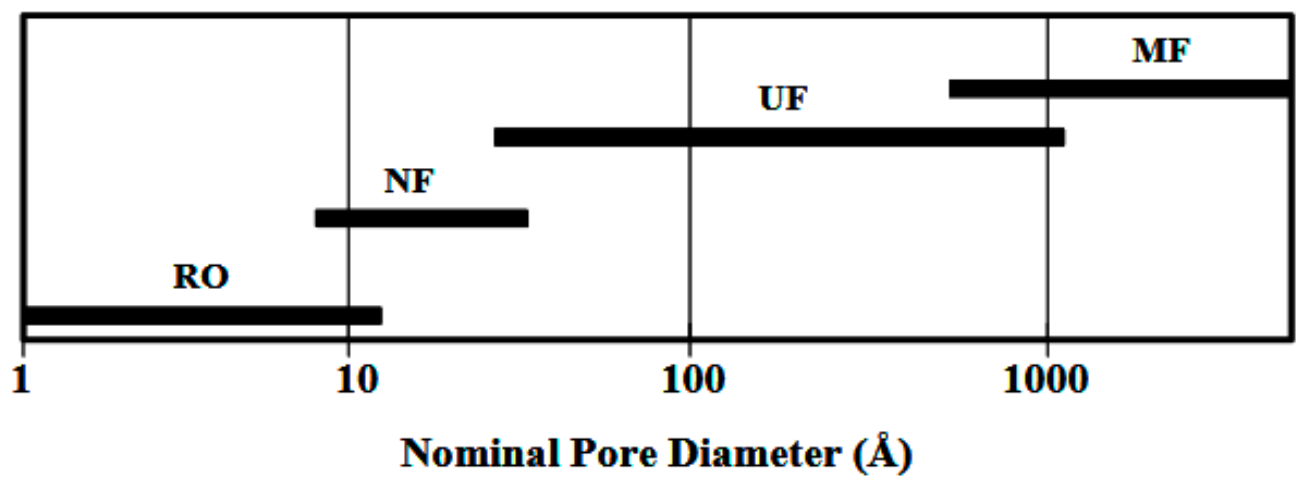

Figure 4. Range of nominal membrane pore sizes.

\section{1. $R O$}

In TFC RO hollow fiber membranes, an ultra-thin membrane is deposited on a microporous substrate. However, it is difficult to make RO HF membranes and so far the use of hollow fibers in RO has not been completely successful.

The hollow fiber modules that have been frequently used for RO have the selective skin on the outer side of the fiber, which creates concentration polarization and enhanced fouling, leading to the decrease in efficiency [14]. Veríssimo et al. [15] presented a new technique for the preparation of RO composite hollow fibers (only for low pressure), with the selective film on the bore side of the fiber. The technique introduced an inert liquid buffer between the aqueous $\mathrm{m}$-phenylene diamine and the organic trimesoylchloride solution. Verissimo et al. [15] used polyetherimide (PEI) hollow fiber membranes with PA coated on the bore side for desalination, etc. By using the organic liquid as the buffer layer, an average water permeability of $0.6 \times 10^{-5} \mathrm{Lm}^{-2} \mathrm{~h}^{-1} \mathrm{~Pa}^{-1}$ and an $\mathrm{NaCl}$ rejection of $99.5 \%$ under a pressure of $10 \times 10^{5} \mathrm{~Pa}$ (10 bar) feed pressure were observed, which is a very high rejection obtained with MPD/TMC based TFC-membranes. It was suggested that the membrane prepared using inert organic liquid was virtually defect free. By treating the membrane with formic acid, the average water permeability was improved $\left(3 \times 10^{-5} \mathrm{~L} \mathrm{~m}^{-2} \mathrm{~h}^{-1} \mathrm{~Pa}^{-1}\right)$, with rejections higher than $95 \%$.

Ni et al. [16] deposited PA layer via IP on a PSF UF hollow fiber membrane and treated it with $\mathrm{NaOCl}$ and polyvinly alcohol (PVA) solution. It was observed that the salt rejection of the membranes increased dramatically after the treatment with the $\mathrm{NaOCl}$ and PVA solution, but the permeate flux decreased slightly. A salt rejection of $96.3 \%$ and pure water flux of $10.9 \mathrm{~L} \cdot \mathrm{m}^{-2} \cdot \mathrm{h}^{-1}$ were obtained when the membrane was treated with $500 \mathrm{ppm}$ of $\mathrm{NaOCl}$ solution and $20 \mathrm{ppm}$ of PVA solution.

Kim and Deng [17] modified the surface of commercial thin-film composite (TFC) membranes (six commercial TFC membranes-three nanofiltration (NF) (NF90, NF270, and DK) and three reverse osmosis (RO) membranes (XLE, BW30, and $\mathrm{SG})$ ) via low-pressure ammonia $\left(\mathrm{NH}_{3}\right)$ plasma treatment. The contact angles of $\mathrm{NH}_{3}$ plasma treated membranes were decreased with increasing plasma treatment time. It was also revealed that modified membranes showed better characteristics in comparison with TFC membranes without modification for water treatment.

SRI's (Stanford Research Institute) Materials Research Laboratory is developing an advanced hollow-fiber membrane for reverse osmosis based on a sulfonated-imidazole (SIM) polymer. It is currently being tested for shipboard desalination of seawater and brackish water. In addition to applications in desalination, membranes are also being explored for other types of water purification, such as to purify water extracted during gas and oil production. (SRI International, Menlo Park, CA, USA)

\subsection{NF}

Significant research work on TFC hollow fiber membranes for application in nanofiltration has been done. Sun et al. [18], for the first time, fabricated dual-layer thin-film composite nanofiltration 
hollow fibers (Torlon ${ }^{\circledR}$ 4000T-MV polyamide-imide (PAI)) via IP of hyper branched polyethyleneimine (HPEI) and isophthaloyl chloride (IPC). The membrane provides minimal transport resistance and sufficient mechanical strength for water permeation under high pressures due to its negatively charged substrate and positively charged selective layer. The possible chemical structure of the interfacially polymerized thin film is proposed in Figure 5.

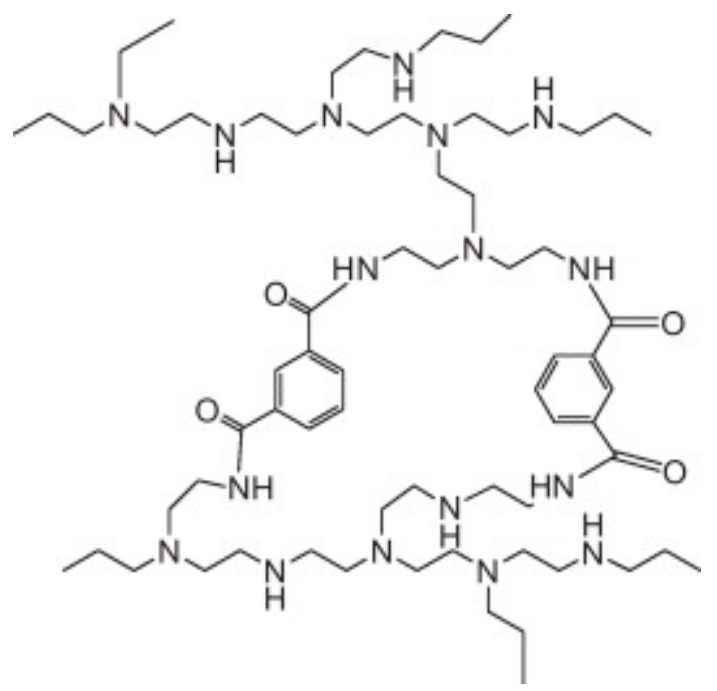

Figure 5. Possible chemical structure of the interfacially polymerized network formed with hyperbranched polyethyleneimine and isophthaloyl chloride [18].

The newly developed NF membrane showed superior rejections (over 99\%) for both positively and negatively charged dye molecules due to the steric-hindrance and the solute electro-neutrality effects (double-repulsion effect). The membrane showed a water permeability of $4.9 \mathrm{~L} \mathrm{~m}^{-2} \mathrm{bar}^{-1} \mathrm{~h}^{-1}$ and an MWCO (molecular weight cut off) of $500 \mathrm{Da}$.

Liu et al. [19] fabricated a high flux thin film composite (TFC) hollow fiber nanofiltration (NF) membrane with a barrier layer of polypiperazine amide synthesized via interfacial polymerization (IP) on a previously prepared dual-layer (PES/PVDF) hollow fiber substrate. The novel hollow fiber NF membrane has a permeability of $16.6 \mathrm{~L} \mathrm{~m}^{-2} \mathrm{~h}^{-1} \mathrm{bar}^{-1}$, an MWCO of $330 \mathrm{Da}$, and a tensile strength of 10.3 MPa.

Zheng et al. [20] prepared positively charged thin-film composite hollow fiber nanofiltration membranes by the dip-coating method using polypropylene hollow fiber microfiltration membrane as the support. The coating materials were polyvinyl alcohol (PVA) and polyquaternium-10 (the reaction product of hydroxyethyl cellulose with a trimethylammonium substituted epoxide, PQ-10), and glutaraldehyde was used as cross-linking agent. By using the submerged filtration technique, it was observed that the rejections of Brilliant Green, Victoria Blue B, and Crystal Violet were 99.8\%, $99.8 \%$, and $99.2 \%$, respectively. It was found that the salt rejection order of the membrane was $\mathrm{CaCl}_{2}>\mathrm{MgCl}_{2}>\mathrm{NaCl}>\mathrm{MgSO}_{4}>\mathrm{Na}_{2} \mathrm{SO}_{4}$ at a neutral $\mathrm{pH}$.

Maurya et al. [21] coated a thin polyamide layer on to PSF hollow fiber via IP (MPD and TMC) under different conditions, and used it for the separation of dyes (reactive black- 5 and rhodamine-B) from water. Depending on the thickness of the PA-PSF membrane, the membranes exhibited about a $60-97 \%$ dye rejection and a product flux of $10-35 \mathrm{~mL} \mathrm{~m}^{-2} \mathrm{~h}^{-1}$.

Yu et al. [22] coated sodium carboxymethyl cellulose (CMCNa) on the outer surface of PP hollow fibers followed by cross-linking with $\mathrm{FeCl}_{3}$, and used it for the removal of anionic dyes (Congo red and Methyl blue) from aqueous solution. It was reported that the membrane's MWCO was about $700 \mathrm{Da}$. The membrane could effectively remove anionic dyes (Congo red and Methyl blue) from aqueous solution. 
Wei et al. [23] removed heavy metals from electroplating wastewater by using thin-film composite nanofiltration (NF) hollow-fiber membranes. TFC NF hollow-fiber membranes (PSF/PES) were prepared by IP technique using PIP and TMC as reactive monomers to form the PA on the inner surface of the hollow-fiber membrane. The membrane showed a pure water flux of approximately $152 \mathrm{~L} \mathrm{~m}^{-2} \mathrm{~h}^{-1}$ at $0.1 \mathrm{MPa}$. The rejection rates for chromium, copper, and nickel ions were $95.76 \%$, $95.33 \%$, and $94.99 \%$, respectively.

Liu et al. [24] fabricated PA/PVDF hollow fiber composite NF membranes by IP on the external surface using TMC and PIP as the IP reaction reagents. It was observed that the rejections of PA/PVDF hollow fiber composite NF membranes for $\mathrm{Na}_{2} \mathrm{SO}_{4}, \mathrm{MgCl}_{2}, \mathrm{KCl}, \mathrm{NaCl}, \mathrm{PEG} 600$, and PEG1000 were $92.3 \%, 7.0 \%, 9.5 \%, 14.2 \%, 88.4 \%$, and $89.3 \%$, respectively.

Plisko et al. [25] developed TFN HF by incorporating fullerenol $\mathrm{C}_{60}(\mathrm{OH})_{22-24}$ into the PA selective layer. The membranes were fabricated via the IP technique by alternately pumping fullerenol into the triethylenetetramine (TETA) aqueous solution and isophthaloyl chloride solution into the hexane through the PSF hollow fiber membranes. It was suggested by the authors that fullerenol may form hydrogen bonds with the amine and amide groups of the polyamide obtained by IP and ester bonds with unreacted acyl chloride groups. Antifouling properties of the membranes were evaluated by the flux changes during alternative filtration of pure water and foulant $-0.4 \mathrm{~g} \mathrm{~L}^{-1}$ lysozyme solution in phosphate buffer $(0.05 \mathrm{M}, \mathrm{pH}=7.0)$. It was revealed that upon incorporation of fullerenol into the PA skin layer, the pure water flux decreased with a slight increase in the lysozyme rejection. It was reported that the properties of the modified membrane were superior to the unmodified membrane.

Abolfazli and Rahimpour [26] investigated the effect of adding silica nanoparticles and TETA (triethylenetetramine) on the permeation performance and morphology of thin-film composite hollow fiber membranes. In this study, PSF HF UF was used as a support layer, and the organic phase that contained TMC and the aqueous phase that contained piperazine, TETA, and $\mathrm{SiO}_{2}$ nanoparticles were used for IP reaction. The TFC skin layer was deposited on the external surface of the hollow fiber. Using a cross-flow hollow fiber filtration setup, membrane performances were investigated by using $2000 \mathrm{ppm}$ of $\mathrm{NaCl}$ as feed at a pressure of 5 bar. It was observed that the salt rejection increased from $15.17 \%$ to $25.44 \%$ when the TETA concentration was increased from $0.5 \%$ to $10 \%(w / v)$. Further, it was also observed that the structure and performance of the composite membrane can be effectively controlled by adjusting the concentration of the additives.

Fang et al. [27] fabricated a composite hollow fiber, with a thin-film selective layer on the inner surface of a PES UF membrane as a substrate. The selective layer was formed by IP using branched PEI and TMC as the monomers in the aqueous and organic phases, respectively. The membrane prepared with the optimized preparation parameters showed a positively charged thin-film selective layer with a PWP of about $17 \mathrm{~L} \mathrm{~m}^{-2} \mathrm{~h}^{-1}$ bar and an MWCO of around $500 \mathrm{Da}$. It was observed that the membrane rejections for $\mathrm{Mg}^{2+}$ and $\mathrm{Ca}^{2+}$ ions were around $90 \%$ and the water flux was about $20 \mathrm{~L} \mathrm{~m}^{-2} \mathrm{~h}^{-1}$ at a 2 bar pressure. It was suggested by the authors that these membranes could be used in water softening applications.

\section{3. $F O$}

FO desalination utilizes osmotic pressure difference between a feed solution (FS) and a draw solution (DS) to drive water across a semi-permeable membrane. Higher rejections to a wide range of contaminants and low membrane fouling compared to the conventional RO process are drawing significant attention to the use of the FO process in water treatment.

Sukitpaneenit and Chung [28] presented TFC FO HFs for forward osmosis (FO) applications. A functional selective polyamide layer was formed by highly reproducible IP on a polyethersulfone (PES) hollow fiber support. PES HF support was made by dual-layer coextrusion technology to form desirable macrovoid-free and fully sponge-like morphology. Figure 6 shows strategies to control the phase inversion process with the aid of coextrusion technology employing a dual-layer spinneret. 


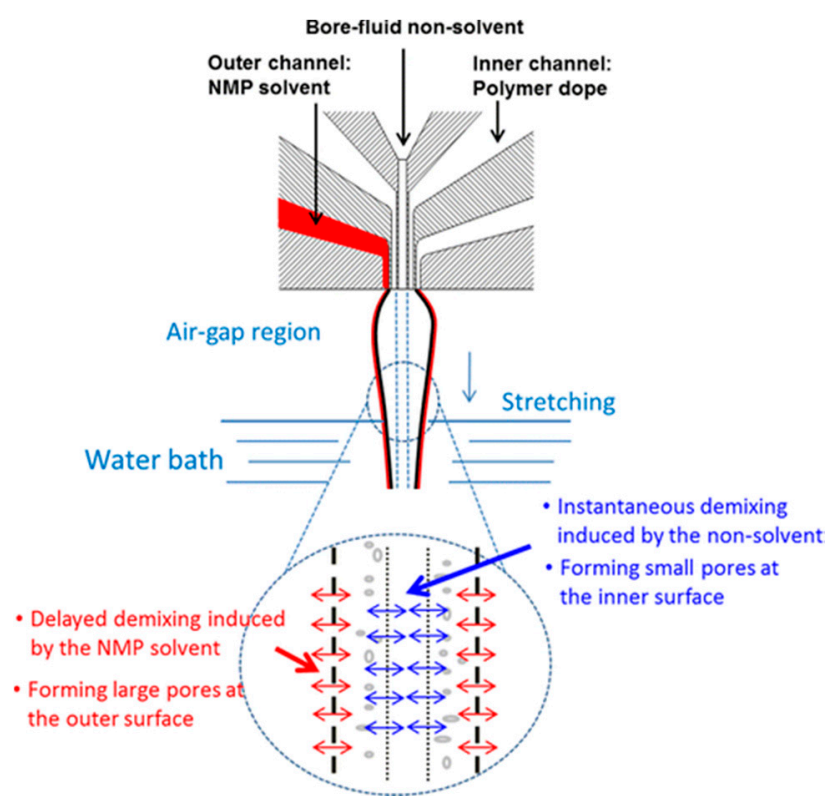

Figure 6. Strategies to control the phase inversion process with the aid of coextrusion technology employing a dual-layer spinneret [28].

The membrane exhibited relatively high water fluxes of $32-34 \mathrm{~L} \mathrm{~m}^{-2} \mathrm{~h}^{-1}$ and up to $57-65 \mathrm{~L} \mathrm{~m}^{-2} \mathrm{~h}^{-1}$ from pure water feed to $2 \mathrm{M} \mathrm{NaCl}$ draw solution tested under the $\mathrm{FO}$ and pressure retarded osmosis (PRO) modes, respectively. Authors claimed that the membranes could display a high water flux up to $15-18 \mathrm{~L} \mathrm{~m}^{-2} \mathrm{~h}^{-1}$ with seawater, which is comparable to the best value reported for seawater desalination applications.

Zhong et al. [29] discussed a new approach to fabricate thin-film composite (TFC) hollow fiber membranes for FO applications. A PA layer via IP was deposited on the lumen side of a hollow fiber, which was fabricated from sulfonated polyphenylenesulfone (PPSU). It was reported that sulfonating plays a role both in creating a macrovoid-free structure and inducing hydrophilicity to bring about higher water fluxes. It was revealed that the resultant membrane exhibited extremely high water fluxes of 30.6 and $82.0 \mathrm{~L} \mathrm{~m}^{-2} \mathrm{~h}^{-1}$ against a pure water feed using $2.0 \mathrm{M} \mathrm{NaCl}$ as the draw solution tested under FO and pressure retarded osmosis (PRO) modes, respectively, while maintaining low salt reverse fluxes below $12.7 \mathrm{~g} \mathrm{~m}^{-2} \mathrm{~h}^{-1}$.

Gang et al. [30] deposited a PA skin onto the outer and inner surfaces of the PES fiber via IP between MPD and TMC, separately. FO and PRO tests were done to see its performance, with the draw solution flowing in the lumen side of the double skin TFC(dTFC)-PES membrane. Superior antifouling performance has been demonstrated by the dTFC-PES membrane when the feed was real wastewater brine (WWBr). The membrane water flux dropped slightly to $71 \%$ of the initial value at a high feed recovery of $80 \%$ in the FO mode. Stable performance was observed in the PRO mode where the power density only decreased to $90.8 \%$ of the initial value after a $12 \mathrm{~h}$ test at $\Delta P=15$ bar. Figure 7 shows the fouling mechanisms of conventional TFC FO membranes and the developed double-skin dTFC-PES membrane. Insignificant fouling was observed on the draw solution side. This phenomenon was due to the outstanding rejection of the polyamide skin facing the draw solution and the transmembrane water permeation from the feed side. 
(a)

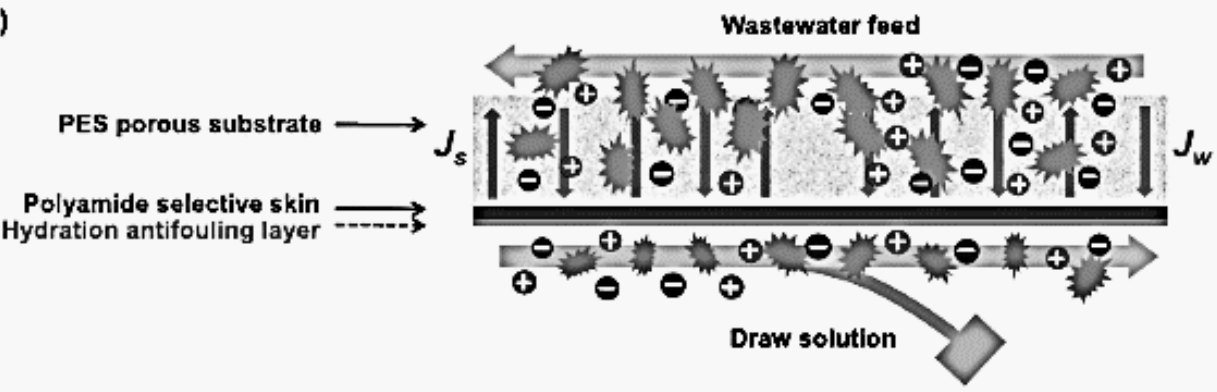

(b)

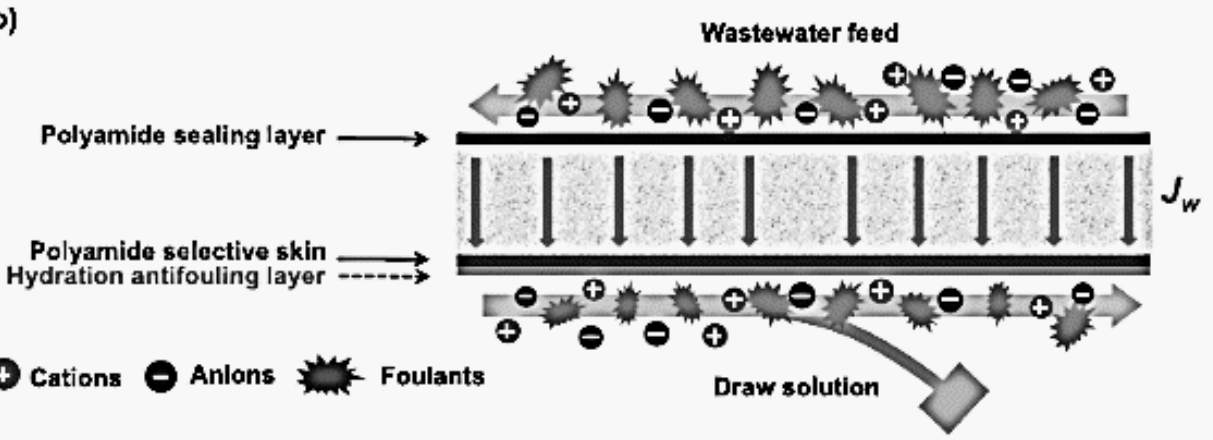

Figure 7. Schematic of fouling phenomena: (a) The conventional thin-film composite (TFC) membrane and (b) the newly developed double-skin TFC membrane in forward osmosis (FO) (under the pressure-retarded osmosis (PRO) mode) and PRO processes [30].

Chou et al. [31] deposited PA layer via IP (MPD-aqueous solution and TMC-hexane solution) on the inner surface of a PES hollow fiber and achieved a water flux of $12.4 \mathrm{~L} \mathrm{~m}^{-2} \mathrm{~h}^{-1}$ for $0.59 \mathrm{M} \mathrm{NaCl}$ feed solution and $2 \mathrm{M} \mathrm{NaCl}$ draw solution. It was suggested by the authors that this new FO hollow membrane has potential for seawater. Chou's membrane also exhibited excellent intrinsic separation properties, with a water flux of $42.6 \mathrm{~L} \mathrm{~m}^{-2} \mathrm{~h}^{-1}$ using $0.5 \mathrm{M} \mathrm{NaCl}$ as the draw solution and DI water as the feed, with the active layer facing the draw solution orientation at $23{ }^{\circ} \mathrm{C}$ [32].

Chung's group [6] designed and fabricated a triangle tri-bore spinneret for the fabrication of TFC HF membranes for FO processes. Using the IP technique, the PA selective layer was deposited on the inner surface of the Matrimid ${ }^{\circledR}$ HF. The fabricated membrane showed an impressive mechanical strength with significant permeation properties. Their group also investigated the effects of glycerol treatment and surfactant concentration during the IP. The newly developed TFC tri-bore HF membranes exhibited high water fluxes of 50.5 and $11.8 \mathrm{~L} \mathrm{~m}^{-2} \mathrm{~h}^{-1}$, with salt leakages as low as 3.5 and $2.5 \mathrm{~g} \mathrm{~m}^{-2} \mathrm{~h}^{-1}$ in the PRO and FO mode, respectively, when using $2 \mathrm{M} \mathrm{NaCl}$ as the draw solution and pure water as the feed. In desalination experiments, the water flux was $5.8 \mathrm{~L} \mathrm{~m}^{-2} \mathrm{~h}^{-1}$ using a $2 \mathrm{M}$ $\mathrm{NaCl}$ draw solution and a model seawater solution as the feed. Theoretically, triangle TFC tri-bore HF membranes have a higher water output per module than the round bore HF at the same packing density due to a larger effective membrane area.

Fang [33] fabricated thin film composite forward osmosis PES hollow fiber membranes by depositing a thin film active layer on the lumen side via IP. Two monomers, i.e., m-phenylenediamine (MPD) and TMC, were used for polymerization. From their studies, it was revealed that two different chemicals can successfully work together as the monomers in the aqueous solution to achieve a better performing membrane than applying each additive separately. Under optimized conditions, the water flux can reach $42.6 \mathrm{~L} \mathrm{~h}^{-1} \mathrm{~m}^{-2}$ using $0.5 \mathrm{M} \mathrm{NaCl}$ as the draw solution with the fabricated membrane. Thus, the performance of the fabricated FO hollow fiber was believed to be superior to all FO membranes reported in the literature.

Shibuya et al. [34] fabricated two types (different inner diameters) of TFC polyketone (as support) HFs with a PA layer on the shell side of the fiber. The PA layer was deposited via IP of TMC and MPD. 
The smaller diameter TFC hollow fiber showed better results than the larger diameter TFC HF in terms of a higher FO flux and better mechanical properties.

Ren and McCutcheon [35] used commercial ultrafiltration hollow fiber membranes (Koch Membrane Systems, Wilmington, MA, USA) as supports for polyamide TFC membranes and tested them for their FO performance. It was revealed the membranes exhibited remarkably good FO performance (both water and solute flux). It suggested that by using these commercial membranes as support material for making TFC, membranes do not need tailoring or adjustment.

\section{4. $P R O$}

PRO can be viewed as an intermediate process between $\mathrm{FO}$ and $\mathrm{RO}$, where hydraulic pressure is applied in the opposite direction of the osmotic pressure gradient (similar to RO). Loeb and Norman [36] proposed a pressure-retarded osmosis (PRO) process. In a PRO process, water flows naturally from a low salinity stream (feed water) at an ambient pressure across a semi-permeable membrane to a pressurized high salinity stream (draw solution) driven by the osmotic pressure difference across the membrane. Chou et al. [37], for the first time, reported the fabrication of TFC HFMs, which could be used in the PRO process. A composite hollow fiber membrane was prepared by depositing a thin layer of PA on a PES hollow fiber via IP. The main reagents used for the IP were MPD, TMC, and cyclohexane. From the performance test, it was revealed that the TFC PRO hollow fiber membranes had a water permeability of $9.22 \times 10^{-12} \mathrm{~m} \mathrm{~s}^{-1} \mathrm{~Pa}^{-1}$, salt permeability of $3.86 \times 10^{-8} \mathrm{~m} \mathrm{~s}^{-1}$, and a structural parameter of $4.6 \times 10^{-4} \mathrm{~m}$.

Ingole et al. [38] developed a high flux and high power density TFC-PRO membrane from the PES membrane support, which was modified by coating with polydopamine (PDA), based on the easy self-polymerization and strong adhesion characteristics of dopamine (DA) under mild conditions. It was found that this improved process resulted in TFC-PRO membranes with simultaneous enhancements in both water permeability and salt rejection properties. On studying the performance of the TFC membrane with the PDA layer, it was revealed that the PDA-TFC membrane has a very high flux, excellent power density performance, and good stability. It was suggested by the authors that these membranes can be used in all engineered osmosis applications, including pressure retarded osmosis.

Wan et al. [39] developed an inner-selective thin-film composite (TFC) PRO HFM with a high operating pressure and a high power density by adding $\mathrm{CaCl}_{2}$, to the PES dope solution when the substrate HF was spun. As the dope solution viscosity increases due to the presence of $\mathrm{CaCl}_{2}$, the resultant membrane had a narrow pore size distribution and smaller pore sizes in comparison with HFs without $\mathrm{CaCl}_{2}$. Air was purged after circulating MPD aqueous solution containing $0.1 \mathrm{wt} \% \mathrm{SDS}$ to make the surface dry. Next, hexane solution with $0.15 \mathrm{wt} \%$ TMC was circulated to react with MPD, resulting in absorption of the polymer on the inner surface of the hollow fiber substrate to form a thin PA selective layer. It was revealed that the TFC-PES membrane had the highest pure water permeability and smallest salt permeability. Further, it showed the highest ever reported power density of $38 \mathrm{~W} \mathrm{~m}^{-2}$ at 30 bar using $1.2 \mathrm{M} \mathrm{NaCl}$ solution and DI water as the draw and feed solutions, respectively.

Although the membrane technology is a well-established and is an advanced method for water treatment, it still needs to solve the problems that arise from membrane fouling and membrane chemical stability. Fouling mitigation will reduce the water production cost by extending the operational life time and lowering energy consumption.

Table 1 summarizes the TFC hollow fiber membranes for water treatment. 
Table 1. TFC hollow fiber membrane for water treatment.

\begin{tabular}{|c|c|c|c|}
\hline TFC HF Membrane & Use & Results & Ref. \\
\hline \multicolumn{4}{|c|}{ Reverse Osmosis } \\
\hline PDA-PES & Desalination & $\begin{array}{l}\text { High flux, excellent power density performance, and good stability. } \\
\text { Can be used in all engineered osmosis applications, including PRO. }\end{array}$ & [15] \\
\hline $\begin{array}{l}\text { PA-PSF, post treated } \\
\text { with } \mathrm{NaOCl} \\
\text { And PVA solution }\end{array}$ & Desalination & Salt rejection of $96.3 \%$ and pure water flux of $10.9 \mathrm{~L} \cdot \mathrm{m}^{-2} \cdot \mathrm{h}^{-1}$. & [16] \\
\hline \multicolumn{4}{|c|}{ Nano filtration } \\
\hline $\begin{array}{l}\text { Polypiperazine } \\
\text { amide-PES/PVDF } \\
\text { (NF) }\end{array}$ & Waste water treatment & High-flux and outstanding selectivity of TOC/TDS. & [19] \\
\hline $\begin{array}{l}\text { PA-PSF } \\
\text { (NF) }\end{array}$ & $\begin{array}{l}\text { Removal of dye etc. } \\
\text { Water treatment }\end{array}$ & $\begin{array}{l}\text { MWCO } 490 \text { to } 730 \mathrm{~g} / \text { mole. Rejections: Reactive black- } 5 \text { and } \\
\text { rhodamine- } 60-97 \% \text {, water flux of } 10-35 \mathrm{~mL} \mathrm{~m}^{-2} \mathrm{~h}^{-1} \text { at } 25 \mathrm{psi} \text {. }\end{array}$ & [21] \\
\hline $\begin{array}{l}\mathrm{CMCNa} / \mathrm{PP} \\
(\mathrm{NF})\end{array}$ & Water treatment & $\begin{array}{l}\text { MWCO } 700 \text { Da. Remove anionic dyes. The dye retention } 99.8 \% \text {, water } \\
\text { permeability } 7.0 \mathrm{~L} \mathrm{~m}^{-2} \mathrm{~h}^{-1} \text { bar, salt rejection } 99.8 \% .\end{array}$ & [22] \\
\hline $\begin{array}{l}\mathrm{PIP}+\mathrm{TMC}-\mathrm{PSF}+\mathrm{PES} \\
(\mathrm{NF})\end{array}$ & Heavy metal removal & $\begin{array}{l}\text { Pure water flux of approximately } 152 \mathrm{~L} \mathrm{~m}^{-2} \mathrm{~h}^{-1} \text { at } 0.1 \mathrm{MPa} \text {. Rejection } \\
\text { rates for chromium, copper, and nickel ions were } 95.76 \%, 95.33 \% \text {, and } \\
94.99 \% \text {, respectively. }\end{array}$ & [23] \\
\hline PA (TMC + PIP)-PVDF & Desalination & $\begin{array}{c}\text { Rejections } \mathrm{Na}_{2} \mathrm{SO}_{4}, \mathrm{MgCl}_{2}, \mathrm{KCl}, \mathrm{NaCl}, \mathrm{PEG} 600 \text { and PEG1000-92.3\%, } \\
\quad 7.0 \%, 9.5 \%, 14.2 \%, 88.4 \% \text {, and } 89.3 \% \text { respectively. }\end{array}$ & [24] \\
\hline Si NPTs + TETA-PSF & Desalination & $\begin{array}{c}\text { Rejection increased from } 15.17 \% \text { to } 25.44 \% \text { with increasing the TETA } \\
\text { concentration from } 0.5 \% \text { to } 10 \%(w / v) \text {. Concentration of additives } \\
\text { affects the structure and performance. }\end{array}$ & [26] \\
\hline \multicolumn{4}{|c|}{ Forward Osmosis, Pressure Retarded Osmosis } \\
\hline $\begin{array}{l}\text { Functional selective PA } \\
\text { layer-PES } \\
\text { (FO, PRO) }\end{array}$ & Desalination application & $\begin{array}{l}\text { Relatively high water fluxes FO } 32-34 \mathrm{~L} \mathrm{~m}^{-2} \mathrm{~h}^{-1} \text {. PRO } 57-65 \mathrm{~L} \mathrm{~m}^{-2} \\
\mathrm{~h}^{-1} \text { (PRO) for pure water feed and } 2 \mathrm{M} \mathrm{NaCl} \text { as the draw solution. } \\
\text { Model seawater solution as the feed, water flux up to } 15-18 \mathrm{~L} \mathrm{~m}^{-2} \mathrm{~h}^{-1} \text {. }\end{array}$ & [28] \\
\hline PA-PPSU & $\begin{array}{l}\text { Desalination in } \\
\text { FO process }\end{array}$ & $\begin{array}{l}\text { FO and PRO. } \\
\text { Higher water flux. }\end{array}$ & [29] \\
\hline $\begin{array}{c}\text { PA-PES } \\
(\mathrm{dTFC}-\mathrm{PES}) \\
(\mathrm{FO}, \mathrm{PRO})\end{array}$ & Waste water treatment & $\begin{array}{l}\text { High feed recovery of } 80 \% \text { in the FO mode. } \\
\text { Stable performance was observed in the PRO mode. }\end{array}$ & [30] \\
\hline $\begin{array}{l}\text { PA-PES } \\
\text { (FO) }\end{array}$ & $\begin{array}{l}\text { Water treatment, } \\
\text { desalination }\end{array}$ & $\begin{array}{l}\text { Water flux } 12.4 \mathrm{~L} \mathrm{~m}^{-2} \mathrm{~h}^{-1} \text { for } 3.5 \mathrm{wt} \% \mathrm{NaCl} \text { feed solution and } 2 \mathrm{M} \\
\qquad \mathrm{NaCl} \text { draw solution. }\end{array}$ & [31] \\
\hline $\begin{array}{l}\text { PA-PES } \\
\text { (FO) }\end{array}$ & $\begin{array}{l}\text { Water treatment, } \\
\text { desalination }\end{array}$ & $\begin{array}{l}\text { Excellent intrinsic separation properties. Water flux of } 42.6 \mathrm{~L} \mathrm{~m}^{-2} \mathrm{~h}^{-1} \\
\text { using } 0.5 \mathrm{M} \mathrm{NaCl} \text { as the draw solution. }\end{array}$ & [32] \\
\hline $\begin{array}{l}\text { PA-Matrimid }{ }^{\circledR} \\
\text { (Tri-bore-composite) } \\
\text { (PRO, FO) }\end{array}$ & Saline water treatment & $\begin{array}{l}\text { High water fluxes of } 50.5 \mathrm{~L} \mathrm{~m}^{-2} \mathrm{~h}^{-1} \text { and } 11.8 \mathrm{~L} \mathrm{~m}^{-2} \mathrm{~h}^{-1} \text { with salt } \\
\text { leakages as low as } 3.5 \text { and } 2.5 \mathrm{~g} \mathrm{~m}^{-2} \mathrm{~h}^{-1} \text {, in PRO and FO modes, when } \\
\text { using } 2 \mathrm{M} \mathrm{NaCl} \text { as the draw solution and pure water as the feed. }\end{array}$ & [6] \\
\hline $\begin{array}{l}\text { PA-polyketone } \\
\text { (IP shell side) }\end{array}$ & Saline water treatment & $\begin{array}{l}\text { HF with smaller diameter -higher FO flux and better mechanical } \\
\text { properties than those larger diameter HF. }\end{array}$ & [34] \\
\hline PA-PES & Desalination & $\begin{array}{l}\text { Under optimized conditions, water flux }-42.6 \mathrm{~L} \mathrm{~h}^{-1} \mathrm{~m}^{-2} \text { using } 0.5 \mathrm{M} \\
\mathrm{NaCl} \text { as draw solution. Superior performance as FO HF. }\end{array}$ & [33] \\
\hline
\end{tabular}




\section{Pervaporation}

\section{Alcohol Dehydration}

The role of alcohols in our daily life is very common as they are widely used as solvents, cleaning agents, raw materials, or chemical intermediates for organic synthesis, industries, and the pharmaceutical and medical fields, etc. In the production and recycling of alcohols, dehydration of the alcohol/water mixture is a critical issue. An azeotropic mixture is formed by alcohol (ethanol, isopropanol, or butanol) and water, which makes purification of alcohols by conventional methods, such as distillation, inefficient and uneconomical. The pervaporation process for the purification of alcohols is energy saving, able to break azeotropes with a high separation efficiency, and is friendly to environment. Thus, industries are showing considerable interest in the pervaporation process for the dehydration/recycling of alcohol mixtures; mostly, it is the separation of the isopropanol-water mixture.

The novel organic-inorganic TFC membranes exhibit pervaporation separation performance surpassing most polymeric membranes and inorganic ceramic membranes previously developed for isopropanol dehydration [40].

Chung and his coworkers $[40,41]$ reported the fabrication and characterization of TFC hollow fiber membranes for the pervaporation dehydration of isopropanol via proper monomer selection and optimal IP reaction.

Sukitpaneenit and Chung [42] fabricated a membrane with a thin selective PA layer, which was formed by IP, onto a porous PES HF support (free of macrovoids) fabricated via dual-layer co-extrusion technology. The surface of the TFC was modified by coating with either polydopamine or silicone rubber. The membrane was used for the separation of the ethanol/water mixture via pervaporation. Both coated membrane exhibited high water separation factors (polydopamine-51; silicone rubber-60) with high fluxes (polydopamine- $6.6 \mathrm{~kg} \mathrm{~m}^{-2} \mathrm{~h}^{-1}$ and silicone rubber-607.5 $\mathrm{kg} \mathrm{m}^{-2} \mathrm{~h}^{-1}$ ).

Zuo et al. [41] developed a novel TFC hollow fiber membrane comprising a PA selective layer on a porous polyamide-imide substrate. Four different amines (m-phenylenediamine (MPD) and three different molecular weight hyper-branched polyethyleneimine (HPEI)) were used for IP for the formation of the thin film on the outer surface of a hollow fiber. These membranes were used for the separation of an isopropyl alcohol (IPA)/water mixture via pervaporation, and it was reported that the TFC membrane fabricated from HPEI with a molecular weight of $2 \mathrm{~kg} \mathrm{~mol}^{-1}$ showed the best separation factor of 624 with a flux of $1282 \mathrm{~g} \mathrm{~m}^{-2} \mathrm{~h}^{-1}$. A permeate water concentration of $99.1 \mathrm{wt} \%$ was obtained with a feed composition of $85 / 15 \mathrm{wt} \%$ The IPA/water was at $50{ }^{\circ} \mathrm{C}$ under the optimal IP conditions.

In another article, Zuo et al. [40] described novel organic-inorganic TFC HF membranes with the introduction of an inorganic component, 3-glycidyloxypropyltrimethoxy-silane (GOTMS), in the chemical structure of the in situ synthesized polyamide layer. The performance testing of these membranes revealed that the separation factor surpassed most prior polymeric membranes and inorganic ceramic membranes for isopropanol dehydration. Flux data obtained from the organic-inorganic TFC HF membranes was $3.5 \mathrm{~kg} \mathrm{~m}^{-2} \mathrm{~h}^{-1}$ with a separation factor of 278 for a feed composition of $85 / 15 \mathrm{wt} \%$ isopropanol (IPA)/water at $50{ }^{\circ} \mathrm{C}$.

Tsai et al. [43] fabricated a dual layer PA/PAN composite hollow fiber membrane via a fabrication technique involving simultaneous extrusion of two different dope solutions by using a triple orifice spinneret. $\mathrm{SiO}_{2}$ was added into the dope to increase the hydrophilicity of the dope. It was found that the PA layer adhered to the lumen surface of the PAN hollow fiber membrane. The membrane performance was studied for the separation of $90 \mathrm{wt} \%$ aqueous isopropanol solution at $25{ }^{\circ} \mathrm{C}$ by pervaporation. A permeation flux of $419 \mathrm{~g} \mathrm{~m}^{-2} \mathrm{~h}^{-1}$ and water content of $96.6 \mathrm{wt} \%$ in permeate was obtained.

Hua et al. [44] described the fabrication of thin-film composite tri-bore hollow fiber (TFC TbHF) membranes for the application of IPA dehydration. By conducting interfacial polymerization on the 
HF substrates, TFC HF membranes were prepared using the monomer, MPD, and another monomer, TMC. The membrane was tested for the dehydration of IPA. It was reported by the authors that the molecularly designed TFC TbHF membranes exhibited excellent pervaporation performance for IPA dehydration. The TFC TbHF membrane showed a flux of $2.65 \mathrm{~kg} \mathrm{~m}^{-2} \mathrm{~h}^{-1}$ with a separation factor of 246 for water/IPA separation at $50{ }^{\circ} \mathrm{C}$ using $85 / 15 \mathrm{wt} \%$ IPA/water as the feed.

In another publication, Hua et al. [45] described the Teflon AF2400/Ultem composite HF membrane preparation with good vapor permeation separation performance, including excellent thermal stability, for alcohol dehydration. The composite HF membranes were fabricated by dip coating a Teflon AF2400 layer on the outer surface of Ultem HFs. Developed composite HF showed a promising and stable separation performance with a flux of $4265 \mathrm{~g} \mathrm{~m}^{-2} \mathrm{~h}^{-1}$ and a separation factor of 383 for $95 \%$ isopropanol dehydration at $125^{\circ} \mathrm{C}$.

Table 2 summarizes TFC hollow fiber membranes for the separation and dehydration of alcohols via pervaporation.

Table 2. TFC hollow fiber membrane for separation and dehydration of alcohols via pervaporation.

\begin{tabular}{|c|c|c|c|}
\hline Membrane & Use & Result & Ref \\
\hline \multicolumn{4}{|c|}{ Pervaporation } \\
\hline $\begin{array}{l}\text { PA (4 different MPD and } 3 \\
\text { different HPEI)-PA + imide }\end{array}$ & Isopropanol dehydration & $\begin{array}{l}\text { Separation factor of } 624 \text {, flux } 1282 \mathrm{~g} \mathrm{~m}^{-2} \mathrm{~h}^{-1} \\
\text { permeate } 99.1 \text { wt } \% \text { water. }\end{array}$ & [41] \\
\hline $\begin{aligned} \text { GOTMS }+ & \text { PA-Poly ether imide } \\
& \left(\text { Ultem }^{\circledR}\right)\end{aligned}$ & Isopropanol dehydration & $\begin{array}{l}\text { Separation performance surpassing } \\
\text { ceramic membranes. }\end{array}$ & {$[40]$} \\
\hline $\begin{array}{l}\text { PA-PES (dual layer), Surface } \\
\text { modified polydopamine or } \\
\text { silicone rubber }\end{array}$ & Ethanol dehydration & $\begin{array}{l}\text { Water separation factors } 51 \text { and } 60 \text {, high fluxes } \\
6.6 \text { and } 7.5 \mathrm{~kg} \mathrm{~m}^{-2} \mathrm{~h}^{-1} \text {. Good } \\
\text { selectivity/separation factors. }\end{array}$ & [42] \\
\hline $\begin{array}{l}\text { PA-PAN }+\mathrm{SiO}_{2} \text { (dual layer, } \\
\text { triple orifice spinneret) }\end{array}$ & $\begin{array}{c}\text { Separation of } \\
90 \mathrm{wt} \% \text { aqueous } \\
\text { isopropanol solution }\end{array}$ & $\begin{array}{l}419 \mathrm{~g} \mathrm{~m}^{-2} \mathrm{~h}^{-1} \text { of permeation flux and } 96.6 \mathrm{wt} \% \\
\text { of water content in permeate. }\end{array}$ & {$[43]$} \\
\hline $\begin{array}{l}\text { Poly (ether imide) Ultem }{ }^{\circledR} \\
1010 \text { (tri-bore hollow fiber) }\end{array}$ & Isopropanol dehydration & $\begin{array}{c}\text { Flux } 2.65 \mathrm{~kg} \mathrm{~m}^{-2} \mathrm{~h}^{-1} \text { with a separation factor of } \\
246 \text { for water/IPA separation at } 50{ }^{\circ} \mathrm{C} \text { using } \\
85 / 15 \mathrm{wt} \% \mathrm{IPA} / \text { water as the feed. }\end{array}$ & [44] \\
\hline $\begin{array}{l}\text { Teflon AF2400 layer on the } \\
\text { outer surface of Ultem HFs } \\
\text { (dip coating) }\end{array}$ & Isopropanol dehydration & $\begin{array}{l}\text { Flux } 4265 \mathrm{~g} \mathrm{~m}^{-2} \mathrm{~h}^{-1} \text {, separation factor } 383 \text { for } \\
95 \% \text { isopropanol dehydration at } 125^{\circ} \mathrm{C} \text {. }\end{array}$ & [45] \\
\hline
\end{tabular}

\section{Gas Separation}

Thin film composite HF membranes for gas separations are usually prepared by coating the membrane surfaces via the dip coating technique. The other technique i.e., IP, is not successful or common.

\subsection{Dip Coating Membranes}

A porous HF, which cannot separate gases to a significant extent, can achieve its intrinsic separation properties by coating with an appropriate material [46]. Henis and Tripodi suggested that the separation properties of coated composite membranes are governed by the porous support material rather than by the coating material, and presented a resistance model to explain the behavior of composite gas separation membranes. Thus, Henis and Tripodi $[47,48]$ developed composite membranes with an acceptable permeability and very high permselectivity $[49,50]$.

The membrane consists of a porous asymmetric substrate of one polymer with a dense layer and a coating of another polymer-a second layer that is made by a non-selective and highly permeable material. On coating, there could be two possibilities:

$\mathrm{i}$ If the pores of the substrate membrane are very large, its gas flow resistance is very low. In this case, the thin layer coated on top of the substrate will govern both the flux and selectivity; or 
ii in the other case, the substrate membrane is considered as a solution diffusion membrane with some defective pores. The substrate governs the membrane performance. The coated layer is only to stop the gas leakage by filling the defective pores.

It is difficult to know which mechanism is working. However, normally, PEBAX coating is thought to be in the first category and PDMS in the second category. However, it is controversial. There could be other influencing factors, such as the chemistry of the membrane, chemistry of the polymers used, and some other unknown factors.

\subsection{IP Membranes}

Few membranes were successfully made by this method for gas separation. Dip coating can also be applied when there are defects in the membrane prepared by IP.

\section{3. $\mathrm{CO}_{2}$ /Methane and $\mathrm{CO}_{2} /$ Nitrogen Separation}

Climate change and global warming is an environmental issue and it is caused mainly due to the rise in $\mathrm{CO}_{2}$ levels in the atmosphere. To lower the atmospheric $\mathrm{CO}_{2}$ concentration, carbon capture and storage (CCS) and the improvement of energy utility are important strategies. Flue gas refers to the combustion exhaust gas produced at power plants. Its composition depends on what is being burned, however, it usually consists of mostly nitrogen (typically more than two-thirds), carbon dioxide $\left(\mathrm{CO}_{2}\right)$, and water vapor. Gas separation membranes have been commercialized for this purpose and are continuously growing [51].

A defect-free PDMS/PAN composite hollow fiber membrane with high performance for flue gas and air separations was fabricated by Liang et al. [52]. The dip coating process was used to make PDMS/PAN composite membranes. The selective layer (PDMS) was $230 \mathrm{~nm}$ thick on PAN HF. From the permeance test, it was found that the $\mathrm{CO}_{2}$ permeance was $>5000 \mathrm{GPU}$ and the $\mathrm{CO}_{2} / \mathrm{N}_{2}$ selectivity was about 11. The developed composite membrane could be used for various gas separations, such as the production of oxygen-enriched air and the separation of $\mathrm{CO}_{2}$ from flue gas. The membrane showed excellent $\mathrm{O}_{2}$ and $\mathrm{CO}_{2}$ permeances higher than 1000 and $5000 \mathrm{GPU}$, respectively, and the selectivity of $\mathrm{O}_{2} / \mathrm{N}_{2}$ and $\mathrm{CO}_{2} / \mathrm{N}_{2}$ were about 2 and 11 , respectively.

Liu et al. [53] fabricated a membrane by coating a thin layer of poly(ether block amide (PEBA) onto microporous PEI hollow fiber substrate membranes. The membrane was prepared by coating a thin layer of PEBA onto microporous PEI hollow fiber substrate membranes. The membrane was tested for $\mathrm{CO}_{2} / \mathrm{N}_{2}$ separation and it was revealed that at $790 \mathrm{kPa}$ a permeate stream containing $62 \mathrm{~mol}$ $\% \mathrm{CO}_{2}$ was obtained, corresponding to $20 \% \mathrm{CO}_{2}$ recovery. On the other hand, $99.4 \mathrm{~mol} \% \mathrm{~N}_{2}$ can be obtained in the residue (nitrogen recovery $72 \%$ ).

Fam et al. [54] prepared defect free Pebax ${ }^{\circledR} 1657 /[\mathrm{emim}]\left[\mathrm{BF}_{4}\right]$ gel membranes in the form of TFC hollow-fiber membranes. On investigation, TFC gel membranes showed excellent mechanical durability, including high packing density. The membrane was used to separate $\mathrm{CO}_{2}$ from a mixed-gas feed containing traces of water vapor and $\mathrm{NO}_{\mathrm{x}}$. From the experimental results, the permeability of $\mathrm{CO}_{2}$ was very high, with $\mathrm{CO}_{2} / \mathrm{N}_{2}$ and $\mathrm{CO}_{2} / \mathrm{CH}_{4}$ selectivity of 36 and 15 , respectively. It was suggested that the TFC gel membranes have the potential application for $\mathrm{CO}_{2}$ capture with a real gas feed.

Lasseuguette et al. [55] used four kinds of TFC hollow fibers membranes for gas separation by using two different porous supports (MicroPES and Oxyphan) and two different permeable polymers (PTMSP and Teflon AF2400) for coating. These membranes exhibited high $\mathrm{CO}_{2}$ and $\mathrm{N}_{2}$ permeability with $\mathrm{CO}_{2} / \mathrm{N}_{2}$ selectivity between 3.4 and 2.5.

Borisov et al. [56] modified polysulfone (PSF) hollow fiber membranes by air plasma and the Piranha etch $\left(\mathrm{H}_{2} \mathrm{O}_{2}+\mathrm{H}_{2} \mathrm{SO}_{4}\right)$ for the development of high efficiency support for composite membrane preparation. For composite membrane formation polymer solution (poly[1-(trimethylsilyl)-1-propyne], (PTMSP) in hexane) was forced in the HF's lumen. The TFC HF fabricated on an air plasma treated surface showed a high $\mathrm{CO}_{2}$ permeance $\left(3.3 \times 10^{5} \mathrm{GPU}\right)$ in comparison with unmodified membranes, including the highest surface energy (more phobic to hydrocarbons). 
Zulhairun et al. [57] coated PDMS containing a $\mathrm{Cu}_{3}(\mathrm{BTC})_{2}$ MOF layer onto a PSF hollow fiber and investigated its gas permeation properties. It was reported that the pure gas permeation experiment with $\mathrm{CO}_{2}, \mathrm{~N}_{2}$, and $\mathrm{CH}_{4}$ corroborated the contribution of the $\mathrm{Cu}_{3}(\mathrm{BTC})_{2}$ particle to the overall composite/hybrid membrane performance. The gas permeation rates were increased with an increasing number of PDMS- $\mathrm{Cu}_{3}(\mathrm{BTC})_{2}$ coatings. $\mathrm{CO}_{2}$ permeance increased from 69.7 to $109.2 \times 10^{-6} \mathrm{~cm}^{3}$ (STP) $/ \mathrm{cm}^{2} \mathrm{~s} \mathrm{cmHg}$ after five consecutive coatings. In addition, the $\mathrm{CO}_{2} / \mathrm{CH}_{4}$ and $\mathrm{CO}_{2} / \mathrm{N}_{2}$ selectivity were found to be increased as well. $\mathrm{Cu}_{3}(\mathrm{BTC})_{2}$ contributed to a higher affinity toward $\mathrm{CO}_{2}$.

\section{4. $\mathrm{SO}_{2}$ Removal}

To capture $\mathrm{CO}_{2}$ from the combustion of fossil fuel plants, $\mathrm{CO}_{2}$ capture and separation (CCS) technologies, which are often based on the chemical absorption process, are used. $\mathrm{The}^{\mathrm{SO}} \mathrm{O}_{2}$ in the emission gas affects the sorbents in the CCS process. Flue gas from coal-power plants contains 6-196 ppm of $\mathrm{SO}_{2}$ after the CCS process. To remove the remaining $\mathrm{SO}_{2}$, another CCS process is necessary. Some studies have been made to apply polymeric membranes for flue gas applications.

Kim et al. [58] prepared a PEBAX/PEI hollow fiber composite membrane via coating poly(ether-b-amide) (PEBAX) onto a PEI hollow fiber and used it to remove $\mathrm{SO}_{2}$ from mixed gases. It was observed that the permeance of $\mathrm{SO}_{2}$ and $\mathrm{CO}_{2}$ increased with the operating pressure. However, the permeance of $\mathrm{N}_{2}$ was negligibly changed. With an increase in temperature, the permeation of $\mathrm{SO}_{2}$ sharply decreased. A similar phenomenon was also observed for the selectivity of $\mathrm{SO}_{2} / \mathrm{CO}_{2}$.

Kim et al. [59] prepared a hollow fiber composite membrane by coating PEI HF with a poly(vinyl chloride)-graft-poly(oxyethylenemethacrylate (PVC-g-POEM)). The inner and outer diameters of the HFM was 261 and $429 \mu \mathrm{m}$, respectively, and the selective coating layer on the outer surface was around $0.1 \mu \mathrm{m}$. The membrane was tested for the permeance of pure gases $\left(\mathrm{SO}_{2}, \mathrm{CO}_{2}\right.$, and $\left.\mathrm{N}_{2}\right)$ at different operating conditions. It was reported that the permeance of $\mathrm{SO}_{2}$ was 105-2705 GPU and the selectivity of $\mathrm{SO}_{2} / \mathrm{CO}_{2}$ was 3.9-175.6. From the mixed gas separation experiment, the maximum $\mathrm{SO}_{2}$ removal efficiency reached $84.5 \%$.

\section{5. $\mathrm{O}_{2} / \mathrm{N}_{2}$ Separation}

Liang et al. [52] reported that the selectivity of $\mathrm{O}_{2} / \mathrm{N}_{2}$ was 2 and permeance of $\mathrm{O}_{2}$ was higher than 1000 GPU with a defect free PDMS/PAN composite hollow fiber membrane. Chong et al. [60] investigated the effects of different coating materials on the separation properties for the oxygen/nitrogen of PSF hollow fiber. The outer surfaces of two PSF hollow fiber were coated with PDMS and PEBAX (poly (ether block amide)) at different concentrations (1,3, and $5 \mathrm{wt} \%)$. It was revealed that the permeance for oxygen gas was in the range of 38-73 GPU, while for nitrogen the range was 10-17 GPU. The uncoated membrane showed 62.35 and 15.11 GPU for the oxygen and nitrogen gas, respectively. Meng et al. [61] used PDMS coated PVDF hollow fiber membranes to study gas permeation $\left(\mathrm{N}_{2} / \mathrm{O}_{2}\right)$. Data obtained experimentally from $\mathrm{N}_{2} / \mathrm{O}_{2}$ permeation supports the data theoretically obtained from the pore distribution model. Liang et al. [62] reported an $\mathrm{N}_{2}$ permeance of about $280 \mathrm{GPU}$, an $\mathrm{O}_{2} / \mathrm{N}_{2}$ selectivity of 2.2 , and a water vapor permeance ranging from about 800 to 3700 GPU for a defect-free thin film composite PDMS/PAN hollow fiber membrane.

Liang et al. [63] fabricated, for the first time, using polymers of intrinsic microporosity (PIMs) for the development of high performance defect free hollow fiber composite membranes via dip coating, and opened a new avenue for future research. The membrane consists of three layers:

i The top selective layer was fabricated from the nucleophilic substitution copolymerization between PIM and beta-cyclodextrin ( $\beta$-CD) (referred to as PIM-CD);

ii polydimethylsiloxane (PDMS) was used as to make a gutter layer; and

iii the material used for the substrate was polyacrylonitrile (PAN). 
The development of a PIM composite hollow fiber was based on the idea to introduce a cross-linked PDMS gutter layer between the PIM-CD selective layer and PAN substrates. Thus, it could mitigate the detrimental solvent effects during the dip coating. In addition, PIM is allowed to adhere onto the gutter layer. Additionally, the gutter layer redistributes the gas transport across the membrane. It was reported that the $\mathrm{O}_{2}$ and $\mathrm{CO}_{2}$ permeances of the membrane were 69 and $483 \mathrm{GPU}$, respectively. The $\mathrm{O}_{2} / \mathrm{N}_{2}$ and $\mathrm{CO}_{2} / \mathrm{N}_{2}$ selectivity was 3.2 and 22.5 , respectively. Further, the $\mathrm{O}_{2} / \mathrm{N}_{2}$ and $\mathrm{CO}_{2} / \mathrm{N}_{2}$ selectivity was increased to 4.2 and 29.5 , respectively, in air separation and flue gas tests.

Pian et al. [64] used a PDMS coated ceramic hollow fiber for oxygen enrichment from air, and achieved an oxygen permeance of $104 \mathrm{GPU}$ with an $\mathrm{O}_{2} / \mathrm{N}_{2}$ ideal selectivity of 2.0. It was suggested that a ceramic hollow fiber-supported PDMS composite membrane could be a competitive oxygen enrichment membrane for industrial application.

\subsection{Water Vapor Transport}

For various applications, such as the dehydration of natural gas, air conditioning, storage of foodstuffs, aviation, and spaceflights, the removal of water vapor from the gas stream is necessary. Condensation and adsorption, which are conventional methods, are uneconomical. On the other hand, membrane technology is better, cheaper, and friendly to the environment.

Ingole et al. [65] fabricated a hydrophilic PA layer on the top of a polydopamine (PDA) coated PES hollow fiber membrane. The hydrophilic PA layer was prepared via IP using 3,5-diaminobenzoic acid (3,5-DABA) as an aqueous phase monomer and trimesoyl chloride (TMC) as an organic phase monomer. The membrane was studied for mixed vapor/gas (water vapor $/ \mathrm{N}_{2}$ mixtures) separation. It was reported that the newly prepared TFC hollow fiber membranes showed a reasonably high selectivity (up to 195) and superior permeation fluxes (up to 3185 GPU).

In another work, Ingole et al. [66] studied the performance of the metal organic framework (MOF) incorporated thin film nanocomposite (TFN) membrane for water vapor transport from the gas mixture, and reported that it drastically enhanced the water vapor transport. The novel membrane is fabricated by depositing a nanocomposite layer of PA (IP of MPD and TMC) with the incorporation of MOF particles. The MOF particles $\mathrm{NH}_{2}$-MIL-125 (Ti) (amine-functionalized titanium metal organic framework) were prepared from $\mathrm{Ti}(\mathrm{BuO})_{4}$ (Titanium butoxide) using reflux and solvothermal reactions [67]. The presence of $0.1 \mathrm{wt} \% \mathrm{MOF}$ nanoparticles increased the permeance from 785 GPU (TFC without MOF) to 2244 GPU (MOF@TFN3) and the selectivity from 116 to 542.

Baig et al. [68] studied water vapor removal using a TFN hollow fiber polyamide-PSF membrane, decorating the surface with carboxylated $\mathrm{TiO}_{2}$ nanoparticles. Surfaces of pure $\mathrm{TiO}_{2}$ were modified by introducing functional groups to increase the hydrophilicity. The presence of modified $\mathrm{TiO}_{2}$ nanoparticles on the membrane surface increased the hydrophilicity of the TFN membrane due to excess carboxylic groups. From the water vapor permeation tests, it was revealed that the water vapor permeance and selectivity drastically increased in comparison with the data obtained for an unmodified membrane. At optimum conditions, the water vapor permeance and selectivity of 1340 GPU and 486, respectively, were obtained.

To produce a covalent organic polymers layer on the surface of a PES hollow fiber, four different aqueous phase monomers, i.e., 1,3-benzenedithiol (BDT), m-phenylenediamine (MPD), 1,3,5-benzenetrithol (BTT), and piperazine (PIP), along with trimesoyl chloride (TMC) for IP, were used by Ingole et al. [69]. Mixed gas, water vapor, and $\mathrm{N}_{2}$ were used to investigate the gas permeation activity of these TFC membranes. A superior result was exhibited by the TFC membrane with BDT for the water vapor permeance (2054 GPU) and the water vapor $/ \mathrm{N}_{2}$ selectivity (119).

Yun et al. [70] deposited a PA layer via IP using 3,5-diaminobenzoic acid (BA) and TMC as the aqueous and organic phase monomers, respectively, on PEs hollow fiber. From the water vapor/nitrogen separation study, it was reported that the best permanence and separation factors were $2160 \mathrm{GPU}$ and 23 , respectively. It suggested that the performance of the TFC membrane depends on the chemistry of the selective layer. 
Ingole et al. [71] synthesized a novel thin film nanocomposite (TFN) membrane hybridized with amino functionalized acid-activated bentonite $(\mathrm{ABn}-\mathrm{NH})$ clay. The membrane was characterized using physicochemical techniques, including X-ray diffraction, BET surface analysis, thermal gravimetric analysis (TGA), Fourier transform infrared (FTIR) spectroscopy, scanning electron microscopy (SEM), atomic force microscopy (AFM), and contact angle analysis. The concentration effect of ABn-NH clay (0-1.0 wt \%) on the permeation of water vapor and $\mathrm{N}_{2}$ was investigated. It was observed that incorporation of $\mathrm{ABn}-\mathrm{NH}$ particles into the polyamide membrane increased the permeance enormously. The best performance of the ABn-NH-TFN-3 membrane (vapor permeance of 2809 GPU and water vapor $/ \mathrm{N}_{2}$ selectivity of 913) was achieved when additive loading was $0.5 \mathrm{wt} \%$.

Table 3 shows the performance of TFC hollow fiber membranes for the separation of gas or gas/water vapor mixtures.

Table 3. TFC hollow fiber membrane for the separation of gas or gas/water vapor mixtures.

\begin{tabular}{|c|c|c|c|}
\hline Membrane & Use & Result & Ref. \\
\hline \multicolumn{4}{|c|}{$\mathrm{CO}_{2} /$ methane and $\mathrm{CO}_{2} /$ nitrogen separation } \\
\hline PEBA-PEI & $\mathrm{CO}_{2} / \mathrm{N}_{2}$ & $\begin{array}{c}\text { Permeate stream containing } 62 \mathrm{~mol} \% \mathrm{CO}_{2} \text { was obtained } \\
\text { at a } \mathrm{CO}_{2} \text { recovery of } 20 \% .99 .4 \mathrm{~mol} \% . \mathrm{N}_{2} \text { in the residue } \\
\text { with a nitrogen recovery of } 36 \% .\end{array}$ & [54] \\
\hline $\begin{array}{l}\text { Four kinds of TFC } \\
\text { composite HFM }\end{array}$ & Gas separation & $\begin{array}{l}\text { High } \mathrm{CO}_{2} \text { and } \mathrm{N}_{2} \text { permeability. } \mathrm{CO}_{2} / \mathrm{N}_{2} \\
\text { selectivity's 3.4-2.5. }\end{array}$ & [55] \\
\hline $\begin{array}{l}\text { Pebax }{ }^{\circledR} 1657 /[\mathrm{emim}]\left[\mathrm{BF}_{4}\right] \text { gel } \\
\text { membranes in the form of thin } \\
\text { film composite hollow } \\
\text { fiber membranes }\end{array}$ & $\begin{array}{l}\text { Separation of } \mathrm{CO}_{2} \\
\text { mixed-gas containing traces } \\
\text { of water vapor and } \mathrm{NO}_{x}\end{array}$ & $\begin{array}{l}\text { Excellent mechanical durability, potential application for } \\
\qquad \mathrm{CO}_{2} \text { capture with real gas feed. }\end{array}$ & [54] \\
\hline $\begin{array}{l}\text { Modified air plasma and the } \\
\text { Piranha etch PTMSP-PSF }\end{array}$ & $\mathrm{CO}_{2}$ permeance & $\begin{array}{l}\text { High permeance }\left(3.3 \times 10^{5} \mathrm{GPU}\right) \text { in comparison with } \\
\text { unmodified membranes including highest surface energy. }\end{array}$ & [56] \\
\hline $\begin{array}{l}\text { PDMS containing } \mathrm{Cu}_{3}(\mathrm{BTC})_{2} \\
\text { MOF-PSF }\end{array}$ & Gas permeation properties & $\begin{array}{l}\mathrm{CO}_{2} \text { permeance increased from } 69.7 \text { to } 109.2 \times 10^{-6} \mathrm{~cm}^{3} \\
(\mathrm{STP}) / \mathrm{cm}^{2} \mathrm{~s} \mathrm{cmHg} . \mathrm{CO}_{2} / \mathrm{CH}_{4} \text { and } \mathrm{CO}_{2} / \mathrm{N}_{2} \\
\text { selectivity increased. }\end{array}$ & [57] \\
\hline \multicolumn{4}{|c|}{$\mathrm{SO}_{2}$ Removal } \\
\hline PEBAX/PEI & $\begin{array}{l}\text { Removal } \mathrm{SO}_{2} \text { from } \\
\text { mixed gases }\end{array}$ & Permeance of $\mathrm{SO}_{2}$ and $\mathrm{CO}_{2}$ increased. & [58] \\
\hline PVC-g-POEM-PEI & $\begin{array}{l}\text { Separation of gases. } \\
\qquad\left(\mathrm{SO}_{2}, \mathrm{CO}_{2}, \mathrm{~N}_{2}\right)\end{array}$ & $\begin{array}{c}\text { Permeation of } \mathrm{SO}_{2} 105-2705 \text { GPU, Selectivity } \\
\mathrm{SO}_{2} / \mathrm{CO}_{2}-3.9-175.6 \text {. Mixed gas separation } \mathrm{SO}_{2} \text { removal } \\
\text { efficiency reached up to } 84.5 \% \text {. }\end{array}$ & [59] \\
\hline \multicolumn{4}{|c|}{$\mathrm{O}_{2} / \mathrm{N}_{2}$ separation } \\
\hline PDMS or PEBAX-PSF (DCo) & Oxygen enrichment & Higher permeance $\mathrm{O}_{2}$ and $\mathrm{N}_{2}$. & {$[60]$} \\
\hline PDMS-PAN (DCo) & Gas separation & $\begin{array}{c}\mathrm{N}_{2} \text { permeance } 280 \mathrm{GPU}, \mathrm{O}_{2} / \mathrm{N}_{2} \text { selectivity of } 2.2 \text {, water } \\
\text { vapor permeance } 800 \text { to } 3700 \mathrm{GPU} \text {. }\end{array}$ & {$[62]$} \\
\hline PVDMS-PVDF (DCo) & $\begin{array}{c}\text { Gas separation } \\
\left(\mathrm{N}_{2} / \mathrm{O}_{2} \text { separation }\right)\end{array}$ & $\begin{array}{l}\text { Permeability and selectivity were in good agreement with } \\
\text { the theoretical results. }\end{array}$ & [61] \\
\hline PDMS-ceramic (DCo) & Oxygen enrichment from air & Permeance of 104 GPU with $\mathrm{O}_{2} / \mathrm{N}_{2}$ ideal selectivity of 2.0. & [64] \\
\hline PIM-CD/PDMS/PAN & $\begin{array}{l}\text { Gas separation } \\
\mathrm{O}_{2}, \mathrm{~N}_{2} \text { and } \mathrm{CO}_{2}\end{array}$ & $\mathrm{O}_{2} / \mathrm{N}_{2}$ and $\mathrm{CO}_{2} / \mathrm{N}_{2}$ selectivity, 3.2 and 22.5 , respectively. & [63] \\
\hline \multicolumn{4}{|c|}{ Water vapor transport } \\
\hline PDA-PES (DCo) & Water vapor $/ \mathrm{N}_{2}$ mixtures & Excellent selectivity. Permeance 3185 GPU, selectivity 195. & [65] \\
\hline $\begin{array}{l}\text { MOF incorporated TFN } \\
\mathrm{NH}_{2}-\mathrm{MIL}-125 \text { (Ti)-PSF }\end{array}$ & $\begin{array}{l}\text { Water vapor separation from } \\
\text { flue gas }\end{array}$ & $\begin{array}{l}\text { Water vapor permeance increased from } 785 \text { GPU (TFC) to } \\
2244 \text { GPU (MOF@TFN3). Selectivity } 116 \text { to } 542 \text { with } \\
\text { NH2-MIL-125 (Ti) MOF. }\end{array}$ & [66] \\
\hline ABn-NH-TFN-PSf & Water vapor $/ \mathrm{N}_{2}$ & Vapor permeance 2809 GPU, vapor/N 2 selectivity 913. & [69] \\
\hline Carboxylated $\mathrm{TiO}_{2}+$ PA-HF & Flue gas dehydration & Permeance 1340 GPU, selectivity 486. & [68] \\
\hline $\begin{array}{l}\text { BDT, MPD, BTT), PIP-PES } \\
\text { ( } 4 \text { monomers used for IP) }\end{array}$ & Water vapor $/ \mathrm{N}_{2}$ & $\begin{array}{l}\text { BDT exhibited superior results, water vapor permeance } \\
2054 \text { GPU and the water vapor } / N_{2} \text { selectivity } 119 \text {. }\end{array}$ & [71] \\
\hline
\end{tabular}

\section{Summary}

Nowadays, asymmetric thin film composite (TFC) polymeric hollow fiber (HF) membranes are extensively used in industrial gas/vapor separations and water treatment. Many attempts have been 
made during the past decade to develop high flux TFC HFs, however, the following trends are most visible:

(1) Among various methods to coat the thin selective layer on the porous sublayer, dip coating and IP are the most popular for practical applications;

(2) the thin selective layer is developed mostly on the lumen side of the HF;

(3) as for gas/vapor separation, coating of the thin surface layer is done mostly by dip coating. There are only a few examples of IP;

(4) as for water treatment, applications of TFC HFs in FO and PRO are newly investigated for desalination purposes;

(5) in pervaporation, applications of TFC HFs are most encouraging for alcohol dehydration; and

(6) high-performance multiple-layer PIM composite hollow fiber membranes for gas separation open a new avenue for researchers.

Very little work has been done so far for the development of ceramic TFC HFs. At present, TFC HFs are still in the early stage and need more research and development, especially to find the most desirable fabrication conditions. As the membrane technologies are economical, environmentally friendly, and easy to use, they are the leading choice for water purification, gas separation, dehydration of alcohols, separation of liquids, etc. They will continue to be so for many years to come. TFC HF membranes will play a major role for the future advancement of membrane technology.

Funding: This research received no external funding

Conflicts of Interest: The authors declare no conflict of interest.

$\begin{array}{ll}\text { Abbreviations } \\ \text { ABn-NH } & \text { functionalized acid-activated bentonite clay } \\ \text { BDT } & \text { 1,3 benzenedithiol } \\ \text { BTT } & \text { 1,3,5-benzenetrithol } \\ \text { CMCNa } & \text { sodium carboxymethyl cellulose } \\ \text { 3,5-DABA } & \text { 3,5-diaminobenzoic acid } \\ \text { DCo } & \text { Dip coating } \\ \text { DI } & \text { deionized } \\ \text { DMS } & \text { Dimethylsiloxane } \\ \text { FS } & \text { functional selective } \\ \text { GOTMS } & \text { 3-glycidyloxypropyltrimethoxy-silane } \\ \text { HFM } & \text { Hollow fiber membrane } \\ \text { HPEI } & \text { hyper branched polyethyleneimine } \\ \text { IP } & \text { interfacial polymerization } \\ \text { IPC } & \text { isophthaloyl chloride } \\ \text { MPD } & \text { m-phenylenediamine } \\ \text { MWCO } & \text { molecular weight cut off } \\ \text { NF } & \text { Nanofiltration } \\ \text { NPTs } & \text { Nanoparticles } \\ \text { PAN } & \text { Polyacrylonitrile } \\ \text { PAI } & \text { polyamide-imide } \\ \text { PDA } & \text { Polydopamine } \\ \text { PDMS } & \text { Polydimethylsiloxane } \\ \text { PEBAX } & \text { poly(ether block amide) } \\ \text { PES } & \text { Polyethersulfone } \\ \text { PIMs } & \text { polymers of intrinsic microporosity } \\ \text { PIP } & \text { Piperazine } \\ & \end{array}$




$\begin{array}{ll}\text { PK } & \text { Polyketone } \\ \text { PP } & \text { Polypropylene } \\ \text { PPSU } & \text { Polyphenylenesulfone } \\ \text { PQ-10 } & \text { polyquaternium-10 } \\ \text { PRO } & \text { Pressure retarded osmosis } \\ \text { PSF } & \text { Polysulfone } \\ \text { PTMSP } & \text { poly[1-(trimethylsilyl)-1-propyne } \\ \text { PVA } & \text { polyvinyl alcohol } \\ \text { PVDF } & \text { Polyvinylene fluoride } \\ \text { PVP } & \text { poly (4-vinyl pyridine) } \\ \text { PWF } & \text { pure water flux } \\ \text { RO } & \text { reverse osmosis } \\ \text { SIR } & \text { Silicon rubber } \\ \text { TDS } & \text { total dissolved solids } \\ \text { TEOS } & \text { tetraethylorthosilicate } \\ \text { TEPA } & \text { Tetraethylenepentamine) } \\ \text { TETA } & \text { Triethylenetetramine } \\ \text { TFC } & \text { thin film composite } \\ \text { TFM } & \text { thin film membrane } \\ \text { TFN } & \text { thin film nanocomposite } \\ \text { Ti(OBu })_{4} & \text { Titanium butoxide } \\ \text { TMC } & \text { trimesoyl chloride } \\ \text { TOC } & \text { total organic carbon } \\ & \end{array}$

\section{References}

1. Encyclopedia of Life Support Systems (Eolss): Volume 1: Desalination and Water Resources (Desware): Membrane Processes; EOLSS Publishers Co Ltd.: Oxford, UK, 2010; ISBN 978-1-84826-877-7.

2. Van der Meer, W.G.J.; van Dijk, J.C. Theoretical optimization of spiral-wound and capillary nanofiltration modules. Desalination 1997, 113, 129-146. [CrossRef]

3. Petersen, R.J.; Cadotte, J.E. Thin Film Composite Reverse Osmosis Membranes. In Handbook of Industrial Membrane Technology; Noyes Press: Park Ridge, NJ, USA, 1990; Chapter 5; p. 308.

4. Cadotte, J.E. Interfacially Synthesized Reverse Osmosis Membrane. U.S. Patent 4,277,344, 7 July 1981.

5. Vinogradov, N.E.; Kagramanov, G.G. The development of polymer membranes and modules for air separation. J. Phys. Conf. Ser. 2016, 751, 012038. [CrossRef]

6. Luo, L.; Wang, P.; Zhang, S.; Han, G.; Chung, T.S. Novel thin-film composite tri-bore hollow fiber membrane fabrication for forward osmosis. J. Membr. Sci. 2014, 461, 28-38. [CrossRef]

7. Pandey, P.; Chauhan, R.S. Membranes for gas separation. Prog. Polym. Sci. 2001, 26, 853-893. [CrossRef]

8. Li, Z.Y.; Maeda, H.; Kusakabe, R.; Morooka, S.; Anzai, H.; Akiyama, S. Preparation of palladium-silver alloy membranes for hydrogen separation by the spray pyrolysis method. J. Membr. Sci. 1993, 78, 247-254. [CrossRef]

9. Rahaman, M.N. Ceramic Processing; CRC Press: Boca Raton, FL, USA, 2007; pp. 242-244; ISBN 0-8493-7285-2.

10. Quéré, D. Fluid coating on a fiber. Annu. Rev. Fluid Mech. 1999, 31, 347-384. [CrossRef]

11. De Ryck, A.; Quéré, D. Fluid Coating from a Polymer Solution. Langmuir 1998, 14, 1911-1914. [CrossRef]

12. Urper, G.M.; Reyhan, S.T.; Turker, T.; Esra, A.G.; Volodmyr, T.; Ismail, K. Hollow fiber nanofiltration membranes: A comparative review of interfacial polymerization and phase inversion fabrication methods. Sep. Sci. Technol. 2017, 52, 2120-2136. [CrossRef]

13. Perry, R.H.; Green, D.W. (Eds.) Perry's Chemical Engineer's Hand Book, 7th ed.; McGraw Hill: New York, NY, USA, 1997.

14. Tadros, S.E.; Trehu, Y.M. Coating Process for Composite Reverse Osmosis Membranes. U.S. Patent 4,980,061, 25 December 1990.

15. Veríssimo, S.; Peinemann, K.V.; Bordado, J. Thin-film composite hollow fiber membranes: An optimized manufacturing method. J. Membr. Sci. 2005, 264, 48-55. [CrossRef] 
16. Ni, L.; Wang, J.; Zhang, Y.; Meng, J.; Jhang, Y. The performance improvement of hollow fiber composite reverse osmosis membranes by post-treatments. Desalin. Water Treat. 2011, 34, 32-36. [CrossRef]

17. Kim, E.S.; Deng, B. Effect of $\mathrm{NH}_{3}$ plasma on thin-film composite membrane: Relationship of membrane and plasma properties. Membr. Water Treat. 2013, 4, 109-126. [CrossRef]

18. Sun, S.P.; Hatton, T.A.; Chan, S.Y.; Chung, T.S. Novel thin-film composite nanofiltration hollow fiber membranes with double repulsion for effective removal of emerging organic matters from water. J. Membr. Sci. 2012, 401-402, 152-162. [CrossRef]

19. Liu, T.Y.; Bian, L.X.; Yuan, H.G.; Pang, B.; Lin, Y.K.; Tong, Y.T.; der Bruggen, B.V.; Wang, X.L. Fabrication of a high-flux thin film composite hollow fiber nanofiltration membrane for wastewater treatment. J. Membr. Sci. 2015, 478, 25-36. [CrossRef]

20. Zheng, Y.; Yao, G.; Cheng, Q.; Yu, S.; Liu, M.; Gao, C. Positively charged thin-film composite hollow fiber nanofiltration membrane for the removal of cationic dyes through submerged filtration. Desalination 2013, 328, 42-50. [CrossRef]

21. Maurya, S.K.; Parashuram, K.; Singh, P.S.; Ray, P.; Reddy, A.V.R. Preparation of polysulfone-polyamide thin film composite hollow fiber nanofiltration membranes and their performance in the treatment of aqueous dye solutions. Desalination 2012, 304, 11-19. [CrossRef]

22. Yu, S.; Chen, Z.; Cheng, Q.; Lu, Z.; Liu, M.; Gao, C. Application of thin film composite hollow fiber membrane to submerged nanofiltration of anionic dye aqueous solutions. Sep. Purif. Technol. 2012, 88, 121-129. [CrossRef]

23. Wei, X.; Kong, X.; Wang, S.; Xiang, H.; Wang, J.; Chen, J. Removal of heavy metals from electroplating wastewater by thin-film composite nano filtration hollowfiber membranes. Ind. Eng. Chem. Res. 2013, 52, 17583-17590. [CrossRef]

24. Liu, J.Q.; Xu, Z.L.; Li, X.H.; Zhang, Y.; Zhou, Y.; Wang, Z.X.; Wang, X.J. An improved process to prepare high separation performance PA/PVDF hollow fiber composite nanofiltration membranes. Sep. Purif. Technol. 2007, 58, 53-60. [CrossRef]

25. Plisko, T.V.; Liubimova, A.S.; Bildyukevich, A.V.; Penkova, A.V.; Dmitrenko, M.E.; Mikhailovskii, V.Y.; Melnikova, G.B.; Semenov, K.N.; Doroshkevich, N.V.; Kuzminova, A.I. Fabrication and characterization of polyamide-fullerenol thin film nanocomposite hollow fiber membranes with enhanced antifouling performance. J. Membr. Sci. 2018, 51, 20. [CrossRef]

26. Abolfazli, Z.; Rahimpour, A. Fabrication and modification of Thin-film composite hollow fiber NF Membranes. J. Membr. Sci. Res. 2017, 3, 42-49.

27. Fang, W.; Shi, L.; Wang, R. Interfacially polymerized composite nanofiltration hollow fiber membranes for low-pressure water softening. J. Membr. Sci. 2013, 430, 129-139. [CrossRef]

28. Sukitpaneenit, P.; Chung, T.S. High performance thin-film composite forward osmosis hollow fiber membranes with macrovoid-free and highly porous structure for sustainable water production. Environ. Sci. Technol. 2012, 46, 7358-7365. [CrossRef] [PubMed]

29. Zhong, P.; Weber, n.M.; Maletzko, C. Development of Thin-Film Composite forward Osmosis Hollow Fiber Membranes Using Direct Sulfonated Polyphenylenesulfone (SPPSU) as Membrane Substrates. Environ. Sci. Technol. 2013, 47, 7430-7436. [CrossRef] [PubMed]

30. Gang, H.; Cheng, Z.L.; Chung, T.S. Thin-film composite (TFC) hollow fiber membrane with double-polyamide active layers for internal concentration polarization and fouling mitigation in osmotic processes. J. Membr. Sci. 2016, 523, 497-504.

31. Chou, S.; Shi, L.; Wang, R.; Tang, C.Y.; Qiu, C.; Fane, A.G. Characteristics and potential applications of a novel forward osmosis hollow fiber membrane. Desalination 2010, 261, 36-372. [CrossRef]

32. Chou, S. Preparation, Characterization and Optimization of Thin-Film Composite Hollow Fiber Membranes for Osmotically Driven Membrane Processes. Ph.D. Thesis, School of Civil and Environmental Engineering, Singapore Membrane Technology Center, Singapore, 2013.

33. Fang, X.X. Fabrication of thin Film Composite Forward Osmosis Hollow Fiber Membranes. 2018. Available online: https:/ / www.researchgate.net/publication/43945729_Fabrication_of_thinfilm_composite_forward_ osmosis_hollow_fiber_membranes (accessed on 10 January 2018).

34. Shibuya, M.; Yasukawa, M.; Mishima, S.; Tanaka, Y.; Takahashi, T.; Matsuyama, H. A thin-film composite-hollow fiber forward osmosis membrane with a polyketone hollow fiber membrane as a support. Desalination 2017, 402, 33-41. [CrossRef] 
35. Ren, J.; McCutcheon, J.R. Making Thin Film Composite Hollow Fiber Forward Osmosis Membranes at the Module Scale Using Commercial Ultrafiltration Membranes. Ind. Eng. Chem. Res. 2017, 56, 4074-4082. [CrossRef]

36. Loeb, S.; Norman, R.S. Osmotic power plants. Science 1975, 189, 654-655. [CrossRef] [PubMed]

37. Chou, S.; Wang, R.; Shi, L.; She, Q.; Tang, C.; Fane, A.G. Thin-film composite hollow fiber membranes for pressure retarded osmosis (PRO) process with high power density. J. Membr. Sci. 2012, 389, 25-33. [CrossRef]

38. Ingole, P.G.; Choi, W.; Kim, K.H.; Park, C.H.; Choi, W.K.; Lee, H.K. Synthesis, characterization and surface modification of PES hollow fiber membrane support with polydopamine and thin film composite for energy generation. Chem. Eng. J. 2014, 243, 137-146. [CrossRef]

39. Wan, C.F.; Yang, T.; Gai, W.; Lee, Y.D.; Chung, T.S. Thin-film composite hollow fiber membrane with inorganic salt additives for high mechanical strength and high power density for pressure-retarded osmosis. J. Membr. Sci. 2018, 555, 388-397. [CrossRef]

40. Zuo, J.; Wang, Y.; Chung, T.S. Novel organic-inorganic thin film composite membranes with separation performance surpassing ceramic membranes for isopropanol dehydration. J. Membr. Sci. 2013, 433, 60-71. [CrossRef]

41. Zuo, J.; Wang, Y.; Sun, S.P.; Chung, T.S. Molecular design of thin film composite (TFC) hollow fiber membranes for isopropanol dehydration via pervaporation. J. Membr. Sci. 2012, 405, 123-133. [CrossRef]

42. Sukitpaneenit, P.; Chung, T.S. Fabrication and use of hollow fiber thin film composite membranes for ethanol dehydration. J. Membr. Sci. 2014, 450, 124-137. [CrossRef]

43. Tsai, H.A.; Chung, L.H.; Lee, K.R.; Lai, J.Y. The preparation of polyamide/polyacrylonitrile composite hollow fiber membranes for pervaporation. Appl. Mech. Mater. 2013, 377, 246-249. [CrossRef]

44. Hua, D.; Ong, Y.K.; Wang, P.; Chung, T.S. Thin-film composite tri-bore hollow fiber (TFC TbHF) membranes for isopropanol dehydration by pervaporation. J. Membr. Sci. 2014, 471, 155-167. [CrossRef]

45. Hua, D.; Chung, T.S.; Shi, G.M.; Fang, C. Teflon AF2400/Ultem composite hollow fiber membranes for alcohol dehydration by high-temperature vapor permeation. AIChE J. 2016, 62, 1747-1757. [CrossRef]

46. Henis, J.M.S.; Tripodi, M.K. A novel approach to gas separations using composite hollow fiber membranes. Sep. Sci. Technol. 1980, 15, 1059-1068. [CrossRef]

47. Henis, J.M.S.; Tripodi, M.K. Composite hollow fiber membranes for gas permeation: The resistance model approach. J. Membr. Sci. 1981, 8, 233-246. [CrossRef]

48. Henis, J.M.S.; Tripodi, M.K. Multicomponent Membranes for Gas Separations. U.S. Patent 4,230,463, 28 October 1977.

49. Lonsdale, H.K. The growth of membrane technology. J. Membr. Sci. 1982, 10, 81-181. [CrossRef]

50. Baker, R.W. Membrane Separation System; Noyes Data Corporation: Park Ridge, NJ, USA, 1991.

51. Baker, R.W. Future directions of membrane gas separation technology. Ind. Eng. Chem. Res. 2002, 41, 1393-1411. [CrossRef]

52. Liang, C.Z.; Yong, W.F.; Chung, T.S. High-performance composite hollow fiber membrane for flue gas and air separations. J. Membr. Sci. 2017, 541, 367-377. [CrossRef]

53. Liu, L.; Chakma, A.; Feng, X. $\mathrm{CO}_{2} / \mathrm{N}_{2}$ separation by poly(ether block amide) thin film hollow fiber composite membranes. Ind. Eng. Chem. Res. 2015, 44, 6874-6882. [CrossRef]

54. Fam, W.; Mansouri, J.; Li, H.; Chen, V. Improving $\mathrm{CO}_{2}$ separation performance of thin film composite hollow fiber with Pebax®1657/ionic liquid gel membranes. J. Membr. Sci. 2017, 537, 54-68. [CrossRef]

55. Lasseuguette, E.; Rouch, J.C.; Remigy, J.C. Hollow-fiber coating: Application to preparation of composite hollow-fiber membrane for gas separation. Ind. Eng. Chem. Res. 2013, 52, 13146-13158. [CrossRef]

56. Borisov, L.; Ovcharova, A.; Bakhtin, D.; Bazhenov, S.; Volkov, A.; Ibragimov, R.; Gallyamov, R.; Bondarenko, G.; Mozhchil, R.; Bildyukevich, A.; et al. Development of polysulfone hollow fiber porous supports for high flux composite membranes: Air plasma and piranha etching. Fibers 2017, 5, 6. [CrossRef]

57. Fachrurrazi, A.K.Z.Z.G.; Ismail, M.N.I.a.A.F. Asymmetric hollow fiber membrane coated with polydimethylsiloxane-metal organic framework hybrid layer for gas separation. Sep. Purif. Technol. 2015, 146, 85-93.

58. Kim, K.H.; Ingole, P.G.; Kim, J.H.; Lee, H.K. Separation performance of PEBAX/PEI hollow fiber composite membrane for $\mathrm{SO}_{2} / \mathrm{CO}_{2} / \mathrm{N}_{2}$ mixed gas. Chem. Eng. J. 2013, 233, 242-250. [CrossRef]

59. Kim, K.; Hong, S.U.; Kim, J.H.; Lee, H.K. Preparation and performance evaluation of composite hollow fiber membrane for $\mathrm{SO}_{2}$ separation. AIChE J. 2014, 60, 2298-2306. [CrossRef] 
60. Chong, K.C.; Lai, S.O.; Lau, W.J.; Thiam, H.S.; Ismail, A.F.; Roslan, R.A. Preparation, characterization, and performance evaluation of polysulfone hollow fiber membrane with PEBAX or PDMS coating for oxygen enhancement process. Polymers 2018, 10, 126. [CrossRef]

61. Meng, B.; Yang, N.T.; Tan, X.Y.; Zhang, B.Y. Preparation of polyvinylidene fluoride/polyvinyl dimethylsiloxane composite hollow fiber membranes and their separation properties. Chin. J. Polym. Sci. 2005, 23, 75-82. [CrossRef]

62. Liang, C.Z.; Chung, T.S. Robust thin film composite PDMS/PAN hollow fiber membranes for water vapor removal from humid air and gases. Sep. Purif. Technol. 2018, 202, 345-356. [CrossRef]

63. Liang, C.Z.; Liu, J.T.; Lai, J.Y.; Chung, T.S. High-performance multiple-layer PIM composite hollow fiber membranes for gas separation. J. Membr. Sci. 2018, 541, 93-196. [CrossRef]

64. Pian, C.; Shen, J.; Liu, G. Ceramic hollow fiber-supported PDMS composite membranes for oxygen enrichment from air. Asia-Pac. J. Chem. Eng. 2016. [CrossRef]

65. Ingole, P.G.; Choi, W.K.; Baek, I.H.; Lee, H.K. Highly selective thin film composite hollow fiber membranes for mixed vapor/gas separation. RSC Adv. 2015, 5, 78950-78957. [CrossRef]

66. Ingole, P.G.; Sohail, M.; Abou-Elanwar, A.M.; Baig, M.I.; DeokJeon, J.D.; Choi, W.K.; Kim, H.; Lee, H.K. Water vapor separation from flue gas using MOF incorporated thin film nanocomposite hollow fiber membranes. Chem. Eng. J. 2018, 334, 2450-2458. [CrossRef]

67. Sohail, M.; Yun, Y.N.; Lee, E.; Kim, S.K.; Cho, K.; Kim, J.-N.; Kim, T.W.; Moon, J.-H.; Kim, H. Synthesis of highly crystalline $\mathrm{NH}_{2}-\mathrm{MIL}-125$ (Ti) with S-shaped water isotherms for adsorption heat transformation. Cryst. Growth Des. 2017, 17, 1208-1213. [CrossRef]

68. Baig, M.I.; Ingole, P.G.; Choi, W.K.; Park, S.R.; Kang, E.C.; Lee, H.K. Development of carboxylated $\mathrm{TiO}_{2}$ incorporated thin film nanocomposite hollow fiber membranes for flue gas dehydration. J. Membr. Sci. 2016, 514, 622-635. [CrossRef]

69. Ingole, P.G.; Choi, W.K.; Lee, G.B.; Lee, H.K. Thin-film-composite hollow-fiber membranes for water vapor separation. Desalination 2017, 403, 12-23. [CrossRef]

70. Yun, S.H.; Ingole, P.G.; Kim, K.H.; Choi, W.K.; Lee, H.K. Synthesis of cross-linked amides and esters as thin film composite membrane materials yields permeable and selective material for water vapor/gas separation. J. Mater. Chem. A 2015, 3, 7888-7899. [CrossRef]

71. Ingole, P.G.; Baig, I.M.; Pawar, R.R.; Jeon, J.D.; Lee, H.K. Thin film nanocomposite (TFN) hollow fiber membranes incorporated with functionalized acid-activated bentonite (ABn-NH) clay: Towards enhancement of water vapor permeance and selectivity. J. Mater. Chem. A 2017, 5, 20947-20958. [CrossRef] 